\title{
36. AMINO ACIDS AND CARBOHYDRATES IN SEDIMENTS AND INTERSTITIAL WATERS FROM SITE 681, LEG 112, PERU CONTINENTAL MARGIN
}

\author{
R. Seifert, ${ }^{2}$ K.-C. Emeis, ${ }^{3}$ W. Michaelis, ${ }^{2}$ and E. T. Degens ${ }^{2}$
}

\begin{abstract}
Total organic carbon (TOC), dissolved organic carbon (DOC), total hydrolyzable amino acids (THAA), amino sugars (THAS), and carbohydrates (THCHO) were measured in sediments and interstitial waters from Site 681 (ODP Leg 112). TOC concentrations vary between $0.75 \%$ and $8.2 \%$ by weight of dry sediment and exhibit a general decrease with depth. DOC concentrations range from 6.1 to $49.5 \mathrm{mg} / \mathrm{L}$, but do not correlate with TOC concentrations in the sediment. Amino compounds (AA and AS) and sugars account for $0.5 \%$ to $8 \%$ and $0.5 \%$ to $3 \%$ of TOC, respectively, while amino compounds make up between $2 \%$ and $27 \%$ of total nitrogen.

Dissolved hydrolyzable amino acids (free and combined) and amino sugars were found in concentrations from 3.7 to $150 \mu \mathrm{M}$ and from 0.1 to $3.7 \mu \mathrm{M}$, respectively, and together account for an average of $8.5 \%$ of DOC. Dissolved hydrolyzable carbohydrates are in the range of 6 to $49 \mu \mathrm{M}$.

Amino acid spectra are dominated by glycine, alanine, leucine, and phenylalanine; nonproteinaceous amino acids ( $\gamma$-amino butyric acid, $\beta$-alanine, and ornithine) are enriched in the deeper part of the section. $\gamma$-amino butyric acid and $\beta$-alanine are thought to be indicators of continued microbial degradation of TOC. Glycine, serine, glutamic acid, alanine, aspartic acid, and ornithine are the dominating amino compounds in the pore waters. Spectra of carbohydrates in sediments are dominated by glucose, galactose, and mannose, while dissolved sugars are dominated by glucose and fructose.

In contrast to the lack of correlation between abundances of bulk TOC and DOC in corresponding interstitial waters, amino compounds and sugars do show some correlation between sediments and pore waters: A depth increase of aspartic acid, serine, glycine, and glutamic acid in the pore waters is reflected in a decrease in the sediment, while an enrichment in valine, iso-leucine, leucine, and phenylalanine in the sediment is mirrored by a decrease in the interstitial waters. The distribution of individual hexoseamines appears to be related to zones of bacterial decomposition of organic matter. Low glucoseamine to galactoseamine ratios coincide with zones of sulfate depletion in the interstitial waters.
\end{abstract}

\section{INTRODUCTION}

Studies of anoxic surface sediments show that amino acids and carbohydrates are major constituents of the organic matter (e.g., Hamilton and Hedges, 1988; Burdige and Martens, 1988). In the Peru upwelling area, for example, up to $70 \%$ of the total nitrogen in surface sediments is accounted for by amino acids (Henrichs et al., 1984). A consensus is that these compounds and other labile constituents of seston, e.g., carbohydrates, are remineralized rapidly during epigenetic and diagenetic bacterial activity and that only less than $10 \%$ of these compounds are stable enough to be incorporated into the sediment a few centimeters below the sediment/water interface (Degens et al., 1964; Hare, 1973; Seifert et al., in press). While several hypotheses concerning the nature of this more stable portion of inherently labile proteinaceous and storage material have been proposed (for a comprehensive discussion see Henrichs and Doyle, 1986), most investigations have concentrated on a few tens of centimeters at the surface of the sedimentary section. Considering the effects of microbial activity at depths of several tens of meters in rapidly accumulating, organic-matter-rich sediments, such as those on the Peru margin (see Cragg et al., this volume), a need exists for documenting the transformations and abundance of

\footnotetext{
${ }^{1}$ Suess, E., von Huene, R., et al., 1990. Proc. ODP, Sci. Results, 112: College Station, TX (Ocean Drilling Program).

${ }^{2}$ Geologisch-Paläontologisches Institut und Museum, Universităt Hamburg, Bundesstraße 55, D-2000 Hamburg 13, Federal Republic of Germany. 77840 .
}

the labile component of organic matter beyond the immediate surface layer.

Here, we discuss the abundance and composition of amino compounds and carbohydrates in sediments and interstitial waters from Site 681 , where data are available to a depth of 126 meters below sea floor (mbsf). We focus on the relationship between dissolved and particulate amino compounds and sugars and on changes in the composition of these compound classes, which in turn may be attributed to changes in the sedimentary environment.

\section{Study Area}

The sector approximately $50 \mathrm{~km}$ wide and up to a water depth of $500 \mathrm{~m}$ that extends from $6^{\circ}$ to $14^{\circ} \mathrm{S}$, parallel to the coast of Peru, is one of the major areas of biogenic carbon production and burial in the world ocean. A series of forearc basins underlies the upper slope and shelf, which in some cases (i.e., Pisco Basin, Lima Basin, Fig. 1), experienced tectonically induced subsidence of up to $500 \mathrm{~m} / \mathrm{m}$.y. since the middle Miocene, thus creating receptacles for at least part of an immense sediment load (e.g., Suess, von Huene, et al., 1988). Suess et al. (1987) estimated that $2.2 \times 10^{13} \mathrm{~g}$ carbon are produced annually over the Peru shelf at rates of up to 5 $\mathrm{gC} / \mathrm{m}^{2} / \mathrm{d}$, of which approximately $22 \times 10^{10} \mathrm{~g}$ carbon are buried in the sediments; this is approximately $0.24 \%$ of all the marine organic matter buried annually (Romankevich, 1984).

\section{Site 681}

Site $681\left(10^{\circ} 58.7^{\prime} \mathrm{S}\right.$ and $\left.77^{\circ} 56.9^{\prime} \mathrm{W}\right)$ is located in the southernmost sector of the Salaverry Basin, near centers of pronounced coastal upwelling around $11^{\circ} \mathrm{S}$. Here, water depth is only $150 \mathrm{~m}$, and the site coincides with the upper boundary of 


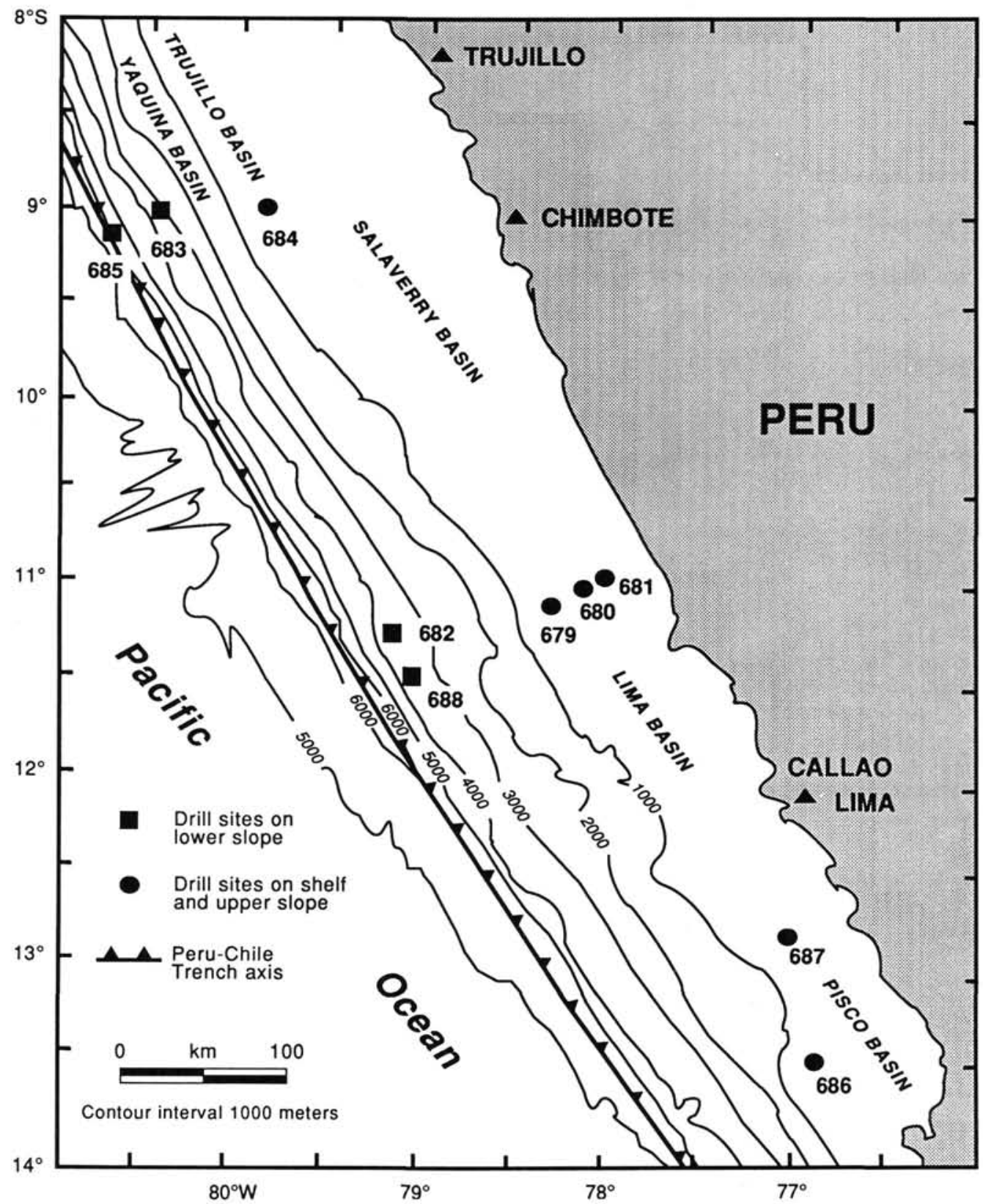

Figure 1. Location map for Site 681 on the Peru margin.

the oxygen-minimum zone that impinges on the Peruvian shelf and upper slope, in which dissolved oxygen concentrations decrease below $0.2 \mathrm{~mL} / \mathrm{L}$. The section recovered comes from the landward side of an outer-shelf mud lens. These sediments are probably entirely Pleistocene in age, and the sedimentation rate for the $187 \mathrm{~m}$ recovered in Hole $681 \mathrm{~A}$ is near 80 $\mathrm{m} / \mathrm{m} . \mathrm{y}$. Paleomagnetic and biostratigraphic correlations showed that sections in all three holes correlate well in depth and facies.

Sedimentological evidence suggests that fluctuations in sea level resulted in shifting of terrestrial influx and in the position of the oxygen-minimum zone. Four lithologic units have been recognized (Fig. 2). Among these, Units I (0 to $36 \mathrm{mbsf}$ in Hole 681A) and Unit III (96 to $135 \mathrm{mbsf}$ in Hole 681A) are characterized by dark gray to olive diatomaceous muds with laminae of diatom ooze. Silt content is high, and graded sand beds are frequent, which attests to proximity of terrigenous sediment sources. Both units are thought to bear the imprint of anoxic or suboxic conditions in the oxygen-minimum zone under alternating "oceanic" or "upwelling" conditions.

Unit II ( 35 to 97 mbsf in Hole 681A) has a more pronounced terrigenous influence, and diatomaceous muds are intensely bioturbated. This major lithology is interspersed with sandy and silty beds, often graded and associated with mollusk beds and shell debris. Phosphorite-rich sand and gravel and erosional beds point to intense current winnowing or shallowwater wave-base erosion. Unit IV (135 to 177 mbsf in Hole 681A) had poor recovery; terrigenous sediments in a facies similar to Unit II were dominated by black and dark gray sands and silty sands.

\section{SAMPLES AND METHODS}

Samples investigated here are listed in Table 1; these cover lithologic Units I, II, and III and include the predominant 


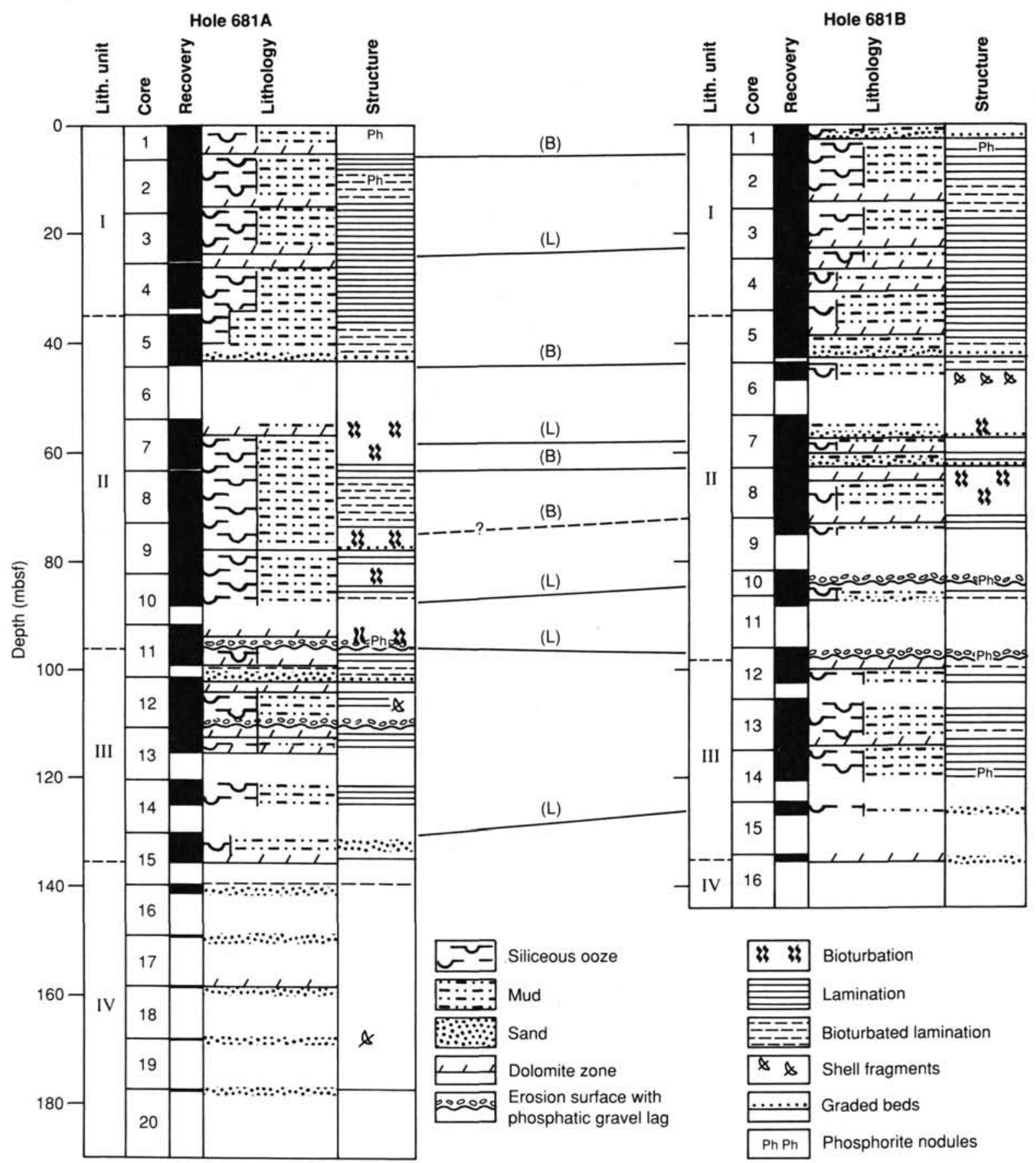

Figure 2. Lithologic and stratigraphic summaries of sediments and sedimentary units recovered at Site 681 .

sediment facies encountered. All interstitial-water samples were obtained by the standard shipboard squeezing technique (Gieskes and Peretsman, 1986), except for two samples (112681A-14X-1I, 0-1 cm, and $-15 \mathrm{X}-1 \mathrm{I}, 0-1 \mathrm{~cm}$ ) obtained from in-situ filtration. Sediment samples were obtained from the squeezed cakes corresponding to the pore water samples. Residues were cleaned with distilled water and scraped free of the periphery of smeared material. Approximately $30 \mathrm{~g}$ from the center of the disk-shaped material was freeze-dried and stored frozen. Two 5-mL aliquots of each interstitial-water sample were sealed in precombusted glass ampoules and immediately frozen. Total organic carbon (TOC) and total nitrogen (TN) analyses of sediment were performed with a
Carlo Erba Model 1104 elemental analyzer after removing carbonate with phosphoric acid. Dissolved organic carbon in the interstitial waters was determined by a Carlo Erba Model 400 total carbon monitor, which involves high-temperature liquid combustion after acidification with nitric acid to remove inorganic carbon dioxide. Amino compounds in squeezed cakes were measured after hydrolysis of 50 - to 150 -mg dried, ground subsamples in $6 \mathrm{~N} \mathrm{HCl}$ under argon for $23 \mathrm{hr}$ at $110^{\circ} \mathrm{C}$. Analyses were performed using a Biotronic amino acid analyzer and quantified vs. standards of known concentration. Dissolved acid-hydrolyzable amino compounds were measured after hydrolysis of 1- to 3-mL sample under the same conditions. Concentration of carbohydrate monomers was 
Table 1. Results of organic geochemical analyses from sediments and interstitial waters, Site 681 .

\begin{tabular}{|c|c|c|c|c|c|c|c|c|c|c|c|c|}
\hline $\begin{array}{l}\text { Core, section, } \\
\text { interval }(\mathrm{cm})\end{array}$ & $\begin{array}{l}\text { Depth } \\
\text { (mbsf) }\end{array}$ & $\begin{array}{l}\text { TOC } \\
(\%)\end{array}$ & $\begin{array}{l}\text { TN } \\
(\%)\end{array}$ & TOC/TN & $\begin{array}{c}\text { THAA } \\
(\mu \mathrm{mol} / \mathrm{g})\end{array}$ & $\begin{array}{c}\text { THAA/TOC } \\
(\%)\end{array}$ & $\begin{array}{c}\text { THAS/TOC } \\
(\%)\end{array}$ & $\begin{array}{c}\text { THAA/TN } \\
(\%)\end{array}$ & $\begin{array}{c}\text { THAS/TN } \\
(\%)\end{array}$ & $\begin{array}{l}\text { DOC } \\
\text { (ppm) }\end{array}$ & $\begin{array}{c}\text { DHAA } \\
(\mu \mathrm{M})\end{array}$ & $\begin{array}{c}\text { DHAA/DOC } \\
(\%)\end{array}$ \\
\hline $112-681 \mathrm{C}-1 \mathrm{H}-1,145-150$ & 1.5 & 6.15 & 0.51 & 12.1 & 45.9 & 3.6 & 1.7 & 15.3 & 4.7 & 29.4 & 33.03 & 5.1 \\
\hline $681 \mathrm{~B}-1 \mathrm{H}-2,67-70$ & 2.2 & 8.22 & 0.72 & 11.4 & 111.1 & 7.0 & 0.6 & 25.4 & 1.6 & n.d. & n.d. & n.d. \\
\hline $681 \mathrm{~B}-1 \mathrm{H}-2,67-70$ & 3.0 & 0.88 & 0.09 & 9.8 & 10.1 & 5.6 & 0.6 & 18.7 & 1.3 & n.d. & n.d. & n.d. \\
\hline $681 \mathrm{C}-1 \mathrm{H}-3,145-150$ & 4.5 & 6.10 & 0.38 & 16.1 & 17.7 & 1.6 & 0.3 & 7.7 & 1.1 & 23.8 & 13.42 & 2.6 \\
\hline $681 \mathrm{C}-1 \mathrm{H}-3,145-150$ & 7.4 & 2.60 & 0.14 & 18.6 & 11.0 & 2.4 & 0.6 & 12.6 & 1.6 & 18.4 & 17.51 & 4.1 \\
\hline $681 \mathrm{C}-1 \mathrm{H}-3,145-150$ & 11.9 & 1.68 & 0.11 & 15.3 & 1.9 & 0.6 & 1.0 & 3.1 & 3.5 & 27.0 & 18.54 & 3.2 \\
\hline $681 \mathrm{C}-1 \mathrm{H}-3,145-150$ & 19.8 & 4.43 & 0.22 & 20.1 & 1.5 & 0.2 & 0.3 & 1.1 & 1.4 & 18.4 & n.d. & n.d. \\
\hline $681 \mathrm{C}-1 \mathrm{H}-3,145-150$ & 27.7 & 5.73 & 0.34 & 16.9 & 7.2 & 0.7 & 1.2 & 3.5 & 4.7 & 27.9 & 3.70 & 0.7 \\
\hline $681 \mathrm{C}-1 \mathrm{H}-3,145-150$ & 32.4 & 3.84 & 0.19 & 20.2 & 6.5 & 1.0 & 0.3 & 5.6 & 1.4 & 31.5 & 36.91 & 5.4 \\
\hline $681 \mathrm{C}-5 \mathrm{H}-3,145-150$ & 38.9 & 3.04 & 0.14 & 21.7 & 2.9 & 0.5 & 1.2 & 3.3 & 6.1 & 26.7 & 14.61 & 2.5 \\
\hline $681 \mathrm{~B}-7 \mathrm{H}-2,140-150$ & 56.3 & 0.92 & 0.09 & 10.2 & 7.7 & 4.2 & 0.3 & 3.0 & 0.7 & 22.2 & 27.25 & 5.9 \\
\hline $681 \mathrm{C}-7 \mathrm{H}-2,140-150$ & 56.4 & 1.18 & 0.09 & 13.1 & 1.7 & 0.8 & 0.2 & 3.2 & 0.7 & 16.2 & 17.47 & 5.2 \\
\hline $681 \mathrm{~B}-8 \mathrm{I}-1,0-1$ & 64.4 & n.d. & n.d. & n.d. & n.d. & n.d. & n.d. & n.d. & n.d. & 11.0 & 20.33 & 7.8 \\
\hline $681 \mathrm{C}-8 \mathrm{H}-2,140-150$ & 65.8 & 1.21 & 0.06 & 20.2 & 1.0 & 0.4 & 0.2 & 2.7 & 0.7 & 15.3 & 44.84 & 15.5 \\
\hline $681 \mathrm{~B}-9 \mathrm{H}-1,140-150$ & 73.8 & 1.48 & 0.11 & 13.5 & 0.4 & 0.2 & 0.3 & 0.6 & 1.0 & 11.6 & n.d. & n.d. \\
\hline $681 \mathrm{C}-9 \mathrm{H}-2,140-150$ & 75.3 & 0.75 & 0.22 & 3.4 & n.d. & n.d. & n.d. & n.d. & n.d. & n.d. & n.d. & n.d. \\
\hline $681 \mathrm{~A}-12 \mathrm{I}-1,0-1$ & 94.4 & n.d. & n.d. & n.d. & n.d. & n.d. & n.d. & n.d. & n.d. & n.d. & 20.93 & n.d. \\
\hline $681 B-12 X-3,140-150$ & 98.9 & 2.11 & 0.15 & 14.1 & 1.0 & 0.3 & 0.5 & 1.1 & 1.6 & 17.7 & 149.97 & 39.9 \\
\hline $681 \mathrm{~B}-15 \mathrm{I}-1,0-1$ & 124.6 & n.d. & n.d. & n.d. & n.d. & n.d. & n.d. & n.d. & n.d. & 6.1 & 12.22 & 9.1 \\
\hline $681 \mathrm{~B}-15 \mathrm{X}-1,135-145$ & 126.0 & 1.03 & 0.05 & 20.6 & 1.0 & 0.6 & 0.2 & 3.5 & 0.9 & 49.5 & n.d. & n.d. \\
\hline
\end{tabular}

measured after acid hydrolysis of 50 - to 100 -mg dried and ground sediment sample or 1- to $3-\mathrm{mL}$ interstitial-water sample. Hydrolysis was conducted with $2 \mathrm{~N} \mathrm{HCl}$ at $100^{\circ} \mathrm{C}$ for 3.5 hr under argon in precombusted glass ampoules. The samples were analyzed and compared with standards using a Biotronik sugar analyzer by liquid chromatography (Table 1) (Mopper, $1977,1978)$ after hydrolysates had been desalted by electrodialysis. Details of all methods are given in Michaelis and Ittekkot (1982).

Samples from the squeezed cakes were not washed before analysis to prevent loss of adsorbed organic material. Some of the salt from the expelled interstitial water may be retained in the (greatly reduced) pore space after squeezing. No weight correction for this salt content was performed. At present, we have no data to aid in deciding whether the squeezing technique (500 tons $/ \mathrm{cm}^{2}$ ) has any effect on the composition of dissolved and particulate organic compounds. However, obvious trends were observed in the downhole distribution of dissolved and particulate compounds; we cannot attribute these trends to sampling artifacts. Comparison with two samples obtained from in-situ filtration indicate dilution with seawater in the filtered samples. We think that the squeezing method yields superior samples even though it may result in enhanced contribution of intracellular (bacterial) biomass.

\section{RESULTS}

\section{Particulate Phases}

TOC, TN, and C/N Ratios

Analyses of the TOC content in sediments of Site 681 averaged $3.02 \%$ (ranging from $0.75 \%$ to $8.22 \%$ ). Concentration of TN correlates with the TOC distribution pattern and ranges from $0.05 \%$ to $0.72 \%$. TOC/TN ratios range from 10 to 22 (mean 15) and exhibit no discernable variation with depth, even though TOC and TN concentrations vary widely with depth and between adjacent sediment intervals. Low concentrations occur in Samples 112-681B-1H-2, 145-150 cm, and $112-681 \mathrm{C}-2 \mathrm{H}-4,145-150 \mathrm{~cm}$, at depths corresponding to lithologies composed of sandy and silty muds. Apparently, the governing mechanism for large fluctuations of TOC is dilution by clastics.

\section{Total Hydrolyzable Amino Acids (THAA)}

Total hydrolyzable amino acids (THAA) ranged in concentration between 0.37 and $111.13 \mu \mathrm{mol} / \mathrm{g}$ dry weight, with a mean value of $14.28 \mu \mathrm{mol} / \mathrm{g}$. Values decrease generally with depth but also show distinct variability, reflecting the downhole distribution of TOC and TN. THAA contribute from $0.15 \%$ to $7.4 \%$ (mean $1.85 \%$ ) and from $0.6 \%$ to $25.4 \%$ (mean $6.9 \%$ ) of TOC and TN, respectively. Both ratios decrease with depth, particularly in the upper part of the profile. The average composition of the THAA spectra (as shown in Fig. 3) is dominated by glycine, alanine, leucine $(>10 \mathrm{~mol} \%)$ and valine, phenylalanine, aspartic acid, iso-leucine, and glutamic acid ( $>5 \mathrm{~mol} \%$ ), which together make up about $75 \mathrm{~mol} \%$ of the THAA. A distinct difference between the THAA spectra of the upper and deeper part is obvious in that acidic amino acids (aspartic acid and glutamic acid) are more abundant in the shallow samples and are uniformly low below $10 \mathrm{mbsf}$. Valine, iso-leucine, leucine, $\beta$-alanine, and $\gamma$-amino butyric acid exhibit a reversed trend (Table 2 ).

\section{Total Hydrolyzable Amino Sugars (THAS)}

Average concentration of total hydrolyzable amino sugars (THAS) is $4.13 \mu \mathrm{mol} / \mathrm{g}$, with a range of 0.31 and $16.99 \mu \mathrm{mol} / \mathrm{g}$. THAS make up $0.15 \%$ to $1.7 \%$ (average $0.6 \%$ ) and $0.7 \%$ to $6.1 \%$ (average $2.1 \%$ ) of TOC and TN, respectively. The ratio between two hexoseamines, glucoseamine (GlcN)/galactoseamine (GalN), varies between 1.38 and 4.05 (mean 1.97) and increases downhole.

\section{Total Hydrolyzable Carbohydrates (THCHO)}

Analyses of total hydrolyzable sugars (THCHO) in sediments resulted in a mean of $6.83 \mu \mathrm{mol} / \mathrm{g}$ dry weight with a range from 0.77 to $35.34 \mu \mathrm{mol} / \mathrm{g}$. Total amount of THCHO as well as their contribution to TOC decreases downhole, with the steepest descent in the upper $10 \mathrm{~m}$ of the core. THCHO contribute between $0.52 \%$ and $2.98 \%$ to TOC. The average THCHO composition is dominated by glucose, mannose, and galactose, each of which account for approximately $20 \mathrm{~mol} \%$ (Fig. 4). Xylose, rhamnose, arabinose, fucose, and fructose concentrations are between 11 and $5.8 \mathrm{~mol} \%$. The downhole distribution pattern of the sugar monomers shows an in- 
Table 1 (continued).

\begin{tabular}{cccc}
\hline $\begin{array}{c}\text { DHAS } \\
(\mu \mathrm{M})\end{array}$ & $\begin{array}{c}\text { DHAS/DOC } \\
(\%)\end{array}$ & $\begin{array}{c}\text { DHCHO } \\
(\mu \mathrm{M})\end{array}$ & $\begin{array}{c}\text { DHCHO/DOC } \\
(\%)\end{array}$ \\
\hline 3.16 & 0.6 & 25.17 & 6.1 \\
n.d. & n.d. & n.d. & n.d. \\
n.d. & n.d. & n.d. & n.d. \\
3.69 & 0.9 & n.d. & n.d. \\
2.19 & 0.7 & 14.36 & 5.4 \\
2.19 & 0.4 & 23.03 & 6.1 \\
n.d. & n.d. & 20.70 & 8.0 \\
1.27 & 0.3 & 23.09 & 5.8 \\
0.72 & 0.1 & 17.18 & 3.8 \\
1.34 & 0.3 & n.d. & n.d. \\
0.12 & 0.0 & 8.87 & 2.7 \\
0.18 & 0.1 & 49.25 & 21.9 \\
0.36 & 0.2 & 10.07 & 6.5 \\
0.05 & 0.0 & 5.81 & 2.7 \\
n.d. & n.d. & n.d. & n.d. \\
n.d. & n.d. & n.d. & n.d. \\
0.76 & n.d. & 30.53 & n.d. \\
2.82 & 1.0 & n.d. & n.d. \\
0.08 & 0.1 & n.d. & n.d. \\
n.d. & n.d. & n.d. & n.d. \\
\hline & & &
\end{tabular}

creased molar contribution of glucose with depth offset by a decrease of fucose. High glucose beside a low fucose contribution appears also in Sample 112-681B-3H-3, 140-150 cm, at a relatively shallow depth within the sediment column $(19.8$ mbsf) (Table 3).

\section{Dissolved Phases}

\section{Dissolved Organic Carbon}

DOC concentrations (listed in Table 1) scatter widely over the entire interval from 0 to $126 \mathrm{mbsf}$ and range from 6.1 to $49.5 \mathrm{mg} / \mathrm{L}$. The lowest DOC contents, at 64.4 and $124.6 \mathrm{mbsf}$, were encountered in the in-situ samples taken by filtration. Based on the elevated sulfate content found in these samples (Suess, von Huene, et al., 1988), we attribute the low DOC concentration of these samples to dilution with seawater. At present, we cannot evaluate the contribution of bacterial cell destruction to DOC, because in-situ filtration did not yield unadulterated interstitial-water samples.

We cannot discern any simple relationship between TOC of the sediment and DOC content of the corresponding pore waters, even though the lowest concentrations of DOC were noted in the organic-lean muds of lithologic Unit II. The highest DOC concentration was measured in the deepest sample from lithologic Unit III, which had a TOC value of only $1 \%$, but which was recovered from the subsurface brine found on the Peru shelf (Suess, von Huene, et al., 1988). The range of DOC found in our samples agrees well with results from Henrichs and Farrington (1984), who measured the upper meter of the Peru upwelling sediment. In spite of the relatively high TOC content, DOC concentrations appear to be low in comparison with other sediments: Michaelis et al. (1982) reported concentrations from 31 to $204 \mathrm{mg} / \mathrm{L}$ from the Gulf of California; Emeis et al. (1987) found values from 48 to $144 \mathrm{mg} / \mathrm{L}$ in interstitial waters from the North Atlantic Ocean, and Seifert et al. (in press) measured DOC at levels from 3 to $100 \mathrm{mg} / \mathrm{L}$ in hemipelagic calcareous muds low in TOC from the Tyrrhenian Sea.

\section{Dissolved Hydrolyzable Amino Acids (DHAA)}

Concentrations of dissolved hydrolyzable amino acids (DHAA) in interstitial water were found to range between 3.7 and $150 \mu \mathrm{M}$, with an average of $30.8 \mu \mathrm{M}$. Thus, $0.7 \%$ to $39.9 \%$ (mean $8.2 \%$ ) of the DOC is composed of DHAA, whereby the highest values occur in the lowermost samples. DHAA are dominated by glycine, serine, glutamic acid ( $>10 \mathrm{~mol} \%)$ followed by alanine, aspartic acid, and ornithine ( $>5 \mathrm{~mol} \%)$, as depicted in Fig. 3. No obvious downhole trend can be seen in the distribution pattern of the individual dissolved amino acids (Table 4).

\section{Dissolved Hydrolyzable Amino Sugars (DHAS)}

Dissolved hydrolyzable amino sugars (DHAS) average $\mathbf{1 . 2}$ $\mu \mathrm{M}$ and range from 0.08 to $3.7 \mu \mathrm{M}$, which constitutes between $0.01 \%$ to $1.0 \%$ of the DOC (mean $0.36 \%$ ). The mean GlcN/4.13.

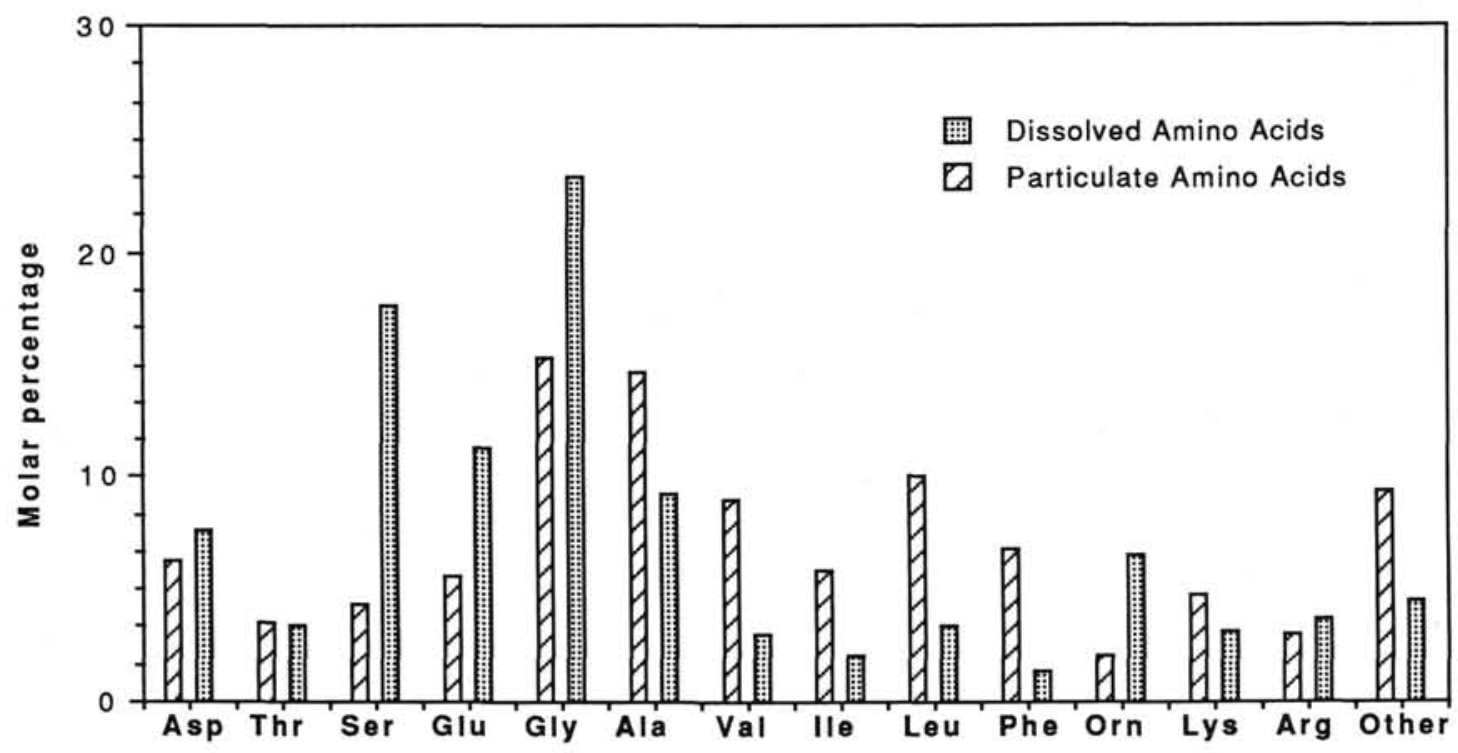

Figure 3. Average distribution of individual amino acid moieties in sediments and pore waters. Asp $=$ aspartic acid, $\mathrm{Thr}=$ threonine, $\mathrm{Ser}=$ serine, $\mathrm{Glu}=$ glutamic acid, $\mathrm{Ala}=$ alanine, $\mathrm{Val}=$ valine, $\mathrm{lle}=$ iso-leucine, Leu $=$ leucine Phe = phenylalanin, Orn = ornithine, Lys = lysine, Arg = arginine. Category "Other" includes methionine, tyrosine, $\beta$-alanine, $\gamma$-amino butyric acid, and histidine. 
Table 2. Amino acids, amino sugars, and glucoseamine/galactoseamine ratios in hydrolysates of sediments from Site 681 .

\begin{tabular}{|c|c|c|c|c|c|c|c|c|c|c|c|}
\hline $\begin{array}{l}\text { Core, section, } \\
\text { interval }(\mathrm{cm})\end{array}$ & $\begin{array}{l}\text { Depth } \\
\text { (mbsf) }\end{array}$ & $\begin{array}{c}\text { THAA } \\
(\mu \mathrm{mol} / \mathrm{g})\end{array}$ & $\underset{(\mathrm{mol} \%)}{\text { Asp }}$ & $\begin{array}{c}\text { Thr } \\
(\mathrm{mol} \%)\end{array}$ & $\underset{(\mathrm{mol} \%)}{\operatorname{Ser}}$ & $\underset{(\mathrm{mol} \%)}{\text { Glu }}$ & $\begin{array}{c}\text { Gly } \\
\text { (mol\%) }\end{array}$ & $\underset{(\mathrm{mol} \%)}{\mathrm{Ala}}$ & $\begin{array}{c}\text { Val } \\
(\mathrm{mol} \%)\end{array}$ & $\begin{array}{c}\text { Met } \\
(\mathrm{mol} \%)\end{array}$ & $\begin{array}{c}\text { Ile } \\
(\mathrm{mol} \%)\end{array}$ \\
\hline $112-681 \mathrm{C}-1 \mathrm{H}-1,145-150$ & 1.5 & 45.9 & 8.1 & 3.5 & 4.0 & 5.3 & 21.9 & 24.8 & 5.7 & 0.3 & 1.9 \\
\hline 681B-1H-2, 67-70 & 2.2 & 111.1 & 14.1 & 6.8 & 6.7 & 9.1 & 18.8 & 11.2 & 5.3 & 0.9 & 3.9 \\
\hline $681 \mathrm{~B}-1 \mathrm{H}-2,67-70$ & 3.0 & 10.1 & 14.4 & 3.6 & 7.5 & 9.5 & 24.1 & 11.0 & 4.8 & 0.3 & 3.2 \\
\hline $681 \mathrm{C}-1 \mathrm{H}-3,145-150$ & 4.5 & 17.7 & 9.2 & 5.6 & 5.6 & 7.2 & 15.2 & 13.5 & 7.4 & 0.1 & 5.5 \\
\hline $681 \mathrm{C}-1 \mathrm{H}-3,145-150$ & 7.4 & 11.0 & 10.0 & 5.8 & 5.5 & 7.2 & 14.0 & 13.1 & 7.6 & 0.5 & 6.3 \\
\hline $681 \mathrm{C}-1 \mathrm{H}-3,145-150$ & 11.9 & 1.9 & 2.6 & 2.4 & 5.1 & 6.8 & 17.4 & 9.4 & 8.7 & 0.9 & 5.7 \\
\hline $681 \mathrm{C}-1 \mathrm{H}-3,145-150$ & 19.8 & 1.5 & 3.1 & 1.7 & 2.5 & 6.3 & 9.8 & 10.4 & 10.4 & 1.0 & 9.0 \\
\hline $681 \mathrm{C}-1 \mathrm{H}-3,145-150$ & 27.7 & 7.2 & 3.0 & 1.6 & 4.0 & 4.4 & 20.0 & 21.8 & 9.4 & 0.8 & 3.7 \\
\hline $681 \mathrm{C}-1 \mathrm{H}-3,145-150$ & 32.4 & 6.5 & 6.6 & 4.5 & 5.0 & 6.6 & 15.8 & 11.6 & 8.6 & 1.4 & 7.8 \\
\hline $681 \mathrm{C}-5 \mathrm{H}-3,145-150$ & 38.9 & 2.9 & 3.2 & 1.2 & 3.4 & 2.6 & 11.5 & 31.4 & 9.7 & 0.9 & 3.6 \\
\hline $681 \mathrm{~B}-7 \mathrm{H}-2,140-150$ & 56.3 & 7.7 & 1.4 & 0.7 & 2.1 & 4.2 & 20.3 & 27.5 & 9.2 & 4.7 & 5.1 \\
\hline $681 \mathrm{C}-7 \mathrm{H}-2,140-150$ & 56.4 & 1.7 & 5.8 & 3.6 & 3.9 & 5.1 & 14.7 & 6.0 & 11.4 & 1.3 & 7.6 \\
\hline $681 \mathrm{~B}-8 \mathrm{I}-1,0-1$ & 64.4 & n.d. & n.d. & n.d. & n.d. & n.d. & n.d. & n.d. & n.d. & n.d. & n.d. \\
\hline $681 \mathrm{C}-8 \mathrm{H}-2,140-150$ & 65.8 & 1.0 & 5.2 & 3.0 & 3.7 & 4.5 & 16.1 & 12.1 & 9.8 & 0.4 & 7.4 \\
\hline $681 \mathrm{~B}-9 \mathrm{H}-1,140-150$ & 73.8 & 0.4 & 3.4 & 2.7 & 2.9 & 3.1 & 7.2 & 10.3 & 15.3 & 0.0 & 7.1 \\
\hline $681 \mathrm{C}-9 \mathrm{H}-2,140-150$ & 75.3 & n.d. & n.d. & n.d. & n.d. & n.d. & n.d. & n.d. & n.d. & n.d. & n.d. \\
\hline $681 \mathrm{~A}-12 \mathrm{I}-1,0-1$ & 94.4 & n.d. & n.d. & n.d. & n.d. & n.d. & n.d. & n.d. & n.d. & n.d. & n.d. \\
\hline $681 B-12 X-3,140-150$ & 98.9 & 1.0 & 3.1 & 1.6 & 3.5 & 4.6 & 12.5 & 7.1 & 10.3 & 1.0 & 8.4 \\
\hline $681 \mathrm{~B}-15 \mathrm{I}-1,0-1$ & 124.6 & n.d. & n.d. & n.d. & n.d. & n.d. & n.d. & n.d. & n.d. & n.d. & n.d. \\
\hline 681B-15X-1, 135-145 & 126.0 & 1.0 & 6.9 & 7.8 & 3.1 & 1.8 & 6.9 & 11.9 & 10.5 & 1.2 & 7.9 \\
\hline
\end{tabular}

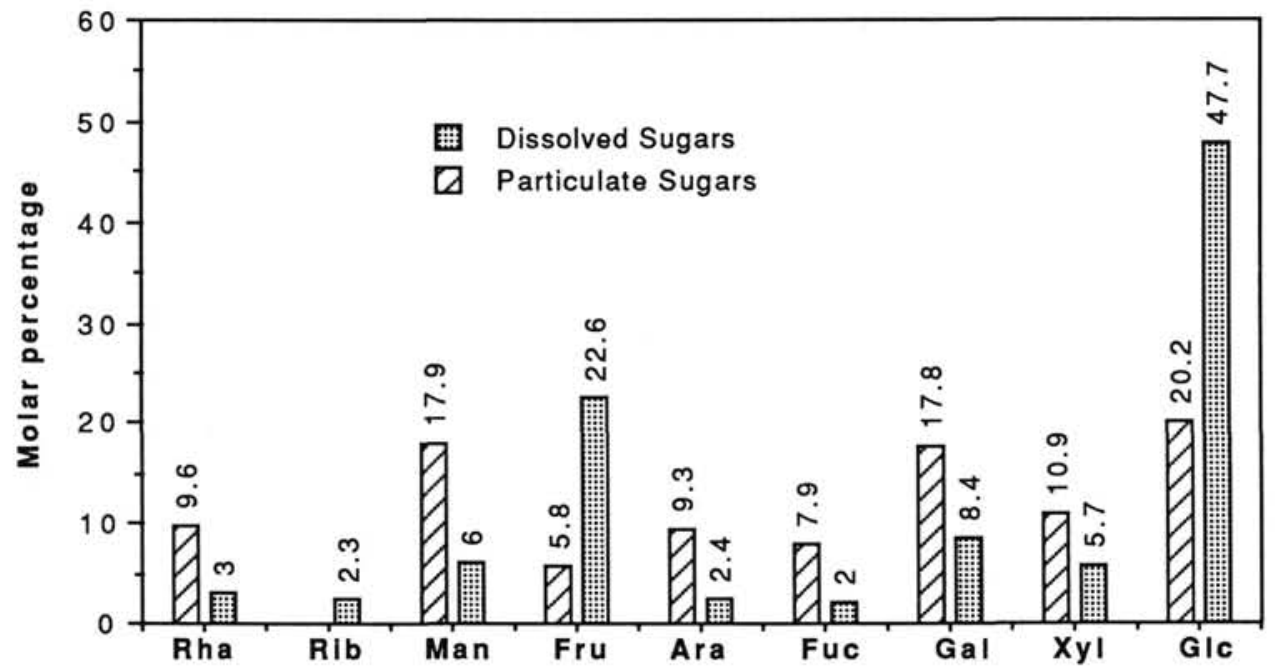

Figure 4. Average distribution of single carbohydrate monomers in sediments and pore waters. Rha $=$ rhamnose, $\mathrm{Rib}=$ ribose, $\mathrm{Man}=$ mannose, Fru $=$ fructose, Ara $=$ arabinose, Fuc $=$ fucose, $\mathrm{Gal}=$ galactose, $\mathrm{Xyl}=$ xylose, $\mathrm{Glc}=$ glucose.

GalN ratio in the dissolved fraction is 1.94 , which is nearly identical to this ratio in the sediments, and varies from 0.9 to

\section{Dissolved Hydrolyzable Carbohydrates (DHCHO)}

Dissolved hydrolyzable sugars (DHCHO) in pore water were found in concentrations from 5.81 up to $49.25 \mu \mathrm{M}$ (mean $20.73 \mu \mathrm{M}$ ), which constitutes $2.7 \%$ to $21.9 \%$ of the DOC (mean $6.9 \%$ ). The monosaccharide spectra of the DHCHO are strongly dominated by glucose and fructose, which make up on average about $70 \mathrm{~mol} \%$. All other monosaccharides occurred in mean molar percentages of total DHCHO between 8.4 and 2 mol\% (Fig. 4). The percentages of glucose and fructose are highest in the deepest sample, while fucose decreases with depth (Table 5).

\section{DISCUSSION}

\section{Amino Compounds}

The distribution pattern of THAA is relatively constant to a depth of 10 mbsf. Glycine is the most abundant amino acid, followed by aspartic acid, alanine, glutamic acid, and serine. The observed distribution of individual amino acids corresponds well to the THAA spectra of comparable surface sediments reported by Henrichs et al. (1984), who did not find a consistent trend in THAA composition. When calculated for the data at Station 5A given by Henrichs et al. (1984) and TOC data given in Henrichs and Farrington (1987), the total amount of THAA and their contribution to TOC decrease by approximately $50 \%$ in the 51-cm-long core studied. Glycine, serine, and threonine are more abundant in the THAA of Peru sediments, compared to studies of sediments with low biogenic opal content (Degens et al., 1964; Seifert et al., in press), even though they are probably underestimated because of the hydrolysis conditions used here. Montani et al. (1982) treated samples with hydrofluoric acid after hydrolysis with $6 \mathrm{~N}$ hydrochloric acid. This HF-fraction made up more than $10 \%$ of the THAA in diatom ooze from the Sea of Okhotsk and was enriched in glycine, serine, and threonine. High concentrations of the hydroxy amino acids serine and threonine are found in diatom cell walls (up to 25 and $10 \mathrm{~mol} \%$, respectively; Hecky et al., 1973) and in sediments of high biogenic opal 
Table 2 (continued).

\begin{tabular}{|c|c|c|c|c|c|c|c|c|c|c|c|c|}
\hline$\underset{(\mathrm{mol} \%)}{\text { Leu }}$ & $\begin{array}{c}\text { Tyr } \\
(\mathrm{mol} \%)\end{array}$ & $\begin{array}{c}\text { Phe } \\
(\mathrm{mol} \%)\end{array}$ & $\begin{array}{c}\beta-A l a \\
(\mathrm{~mol} \%)\end{array}$ & $\begin{array}{c}\gamma \text {-ABA } \\
(\mathrm{mol} \%)\end{array}$ & $\begin{array}{c}\text { Orn } \\
(\mathrm{mol} \%)\end{array}$ & $\begin{array}{c}\text { Lys } \\
(\mathrm{mol} \%)\end{array}$ & $\begin{array}{c}\text { His } \\
(\mathrm{mol} \%)\end{array}$ & $\underset{(\mathrm{mol} \%)}{\operatorname{Arg}}$ & $\begin{array}{l}\text { THAS } \\
(\mu \mathrm{mol} / \mathrm{g})\end{array}$ & $\begin{array}{c}\mathrm{GlcN} \\
(\mathrm{nmol} / \mathrm{g})\end{array}$ & $\begin{array}{c}\text { GaIN } \\
(\mathrm{nmol} / \mathrm{g})\end{array}$ & GlcN/GaIN \\
\hline 3.4 & 2.4 & 3.9 & 1.1 & 0.5 & 8.3 & 0.1 & 1.2 & 3.6 & 16.99 & 9853 & 7135 & 1.38 \\
\hline 5.9 & 2.6 & 4.1 & 0.8 & 0.6 & 0.4 & 3.9 & 1.6 & 3.3 & 8.1 & 4805 & 3293 & 1.46 \\
\hline 4.9 & 1.9 & 3.4 & 1.0 & 0.6 & 0.5 & 4.0 & 1.4 & 3.7 & 0.81 & 497 & 318 & 1.56 \\
\hline 9.8 & 2.4 & 6.4 & 1.2 & 0.8 & 0.6 & 4.8 & 1.1 & 3.3 & 3.11 & 1945 & 1166 & 1.67 \\
\hline 10.7 & 2.5 & 6.4 & 0.8 & 0.9 & 0.7 & 4.1 & 1.3 & 2.4 & 1.63 & 1097 & 544 & 2.02 \\
\hline 9.8 & 2.0 & 5.5 & 3.3 & 4.5 & 4.1 & 6.7 & 1.1 & 4.0 & 2.75 & 1675 & 1079 & 1.55 \\
\hline 16.0 & 2.4 & 9.3 & 2.5 & 2.3 & 2.1 & 7.1 & 0.9 & 3.2 & 2.13 & 1528 & 599 & 2.55 \\
\hline 6.8 & 2.5 & 6.9 & 2.5 & 1.7 & 1.3 & 4.3 & 1.4 & 3.7 & 11.4 & 6899 & 4505 & 1.53 \\
\hline 10.8 & 2.4 & 6.6 & 2.0 & 1.1 & 0.2 & 4.4 & 2.1 & 2.7 & 1.86 & 1150 & 713 & 1.61 \\
\hline 6.8 & 2.3 & 7.0 & 4.0 & 3.1 & 1.7 & 3.7 & 0.8 & 3.1 & 6.12 & 3914 & 2206 & 1.77 \\
\hline 9.3 & 1.6 & 7.4 & 1.4 & 1.5 & 1.8 & 3.9 & 0.6 & 1.7 & 7.63 & 5021 & 2612 & 1.92 \\
\hline 13.7 & 1.5 & 6.4 & 3.2 & 3.0 & 1.3 & 5.2 & 3.7 & 2.7 & 0.43 & 277 & 158 & 1.75 \\
\hline n.d. & n.d. & n.d. & n.d. & n.d. & n.d. & n.d. & n.d. & n.d. & n.d. & n.d. & n.d. & n.d. \\
\hline 12.6 & 0.9 & 6.7 & 1.8 & 1.6 & 1.7 & 5.4 & 4.7 & 2.3 & 0.31 & 202 & 103 & 1.96 \\
\hline 12.9 & 1.4 & 8.5 & 7.4 & 5.1 & 2.2 & 6.5 & 1.7 & 2.6 & 0.75 & 592 & 152 & 3.89 \\
\hline n.d. & n.d. & n.d. & n.d. & n.d. & n.d. & n.d. & n.d. & n.d. & n.d. & n.d. & n.d. & n.d. \\
\hline n.d. & n.d. & n.d. & n.d. & n.d. & n.d. & n.d. & n.d. & n.d. & n.d. & n.d. & n.d. & n.d. \\
\hline 14.9 & 1.8 & 10.9 & 4.0 & 3.7 & 2.6 & 5.9 & 1.6 & 2.4 & 1.66 & 1334 & 329 & 4.05 \\
\hline n.d. & n.d. & n.d. & n.d. & n.d. & n.d. & n.d. & n.d. & n.d. & n.d. & n.d. & n.d. & n.d. \\
\hline 13.0 & 2.5 & 9.2 & 1.6 & 1.2 & 1.9 & 4.7 & 3.8 & 4.0 & 0.32 & 206 & 112 & 1.84 \\
\hline
\end{tabular}

Table 3. Total hydrolyzable carbohydrates and distributions of monomers in sediments from Site 681 .

\begin{tabular}{|c|c|c|c|c|c|c|c|c|c|c|c|}
\hline $\begin{array}{l}\text { Core, section, } \\
\text { interval }(\mathrm{cm})\end{array}$ & $\begin{array}{l}\text { THCHO } \\
(\mu \mathrm{mol} / \mathrm{g})\end{array}$ & $\begin{array}{c}\text { Rha } \\
(\mathrm{mol} \%)\end{array}$ & $\begin{array}{c}\text { Rib } \\
(\mathrm{mol} \%)\end{array}$ & $\underset{(\mathrm{mol} \%)}{\operatorname{Man}}$ & $\begin{array}{c}\text { Fru } \\
(\mathrm{mol} \%)\end{array}$ & $\begin{array}{c}\text { Ara } \\
(\mathrm{mol} \%)\end{array}$ & $\underset{(\mathrm{mol} \%)}{\text { Fuc }}$ & $\underset{(\mathrm{mol} \%)}{\mathrm{Gal}}$ & $\underset{(\mathrm{mol} \%)}{\mathrm{Xyl}}$ & $\begin{array}{c}\text { Glc } \\
(\mathrm{mol} \%)\end{array}$ & $\underset{(\%)}{\mathrm{THCHO} / \mathrm{TOC}}$ \\
\hline $112-681 \mathrm{C}-1 \mathrm{H}-1,145-150$ & 21.13 & 7.2 & 0 & 18.2 & 2.6 & 11.3 & 10.4 & 20.8 & 12.3 & 17.2 & 2.4 \\
\hline 681B-1H-2, 67-70 & 35.34 & 13.5 & 0 & 14.6 & 12.1 & 9.8 & 14.9 & 12.6 & 12.6 & 9.9 & 3.0 \\
\hline $681 B-1 H-2,67-70$ & 2.54 & 10.3 & 0 & 11.8 & 9.7 & 11.1 & 10.6 & 16.9 & 10.5 & 19.1 & 2.0 \\
\hline $681 \mathrm{C}-1 \mathrm{H}-3,145-150$ & 12.23 & 3.9 & 0 & 27.9 & 4.6 & 8.9 & 10.1 & 21.1 & 8.6 & 14.9 & 1.4 \\
\hline $681 \mathrm{C}-1 \mathrm{H}-3,145-150$ & 8.95 & 18.8 & 0 & 12.2 & 6.5 & 10.1 & 10.3 & 15.8 & 12.1 & 14.2 & 2.4 \\
\hline $681 \mathrm{C}-1 \mathrm{H}-3,145-150$ & 6.5 & 5.3 & 0 & 21.1 & 5 & 18.3 & 11.1 & 17.3 & 8.8 & 13.1 & 2.7 \\
\hline $681 \mathrm{C}-1 \mathrm{H}-3,145-150$ & 5.87 & 7.7 & 0 & 20.4 & 6.8 & 5.6 & 4.9 & 18.7 & 9.4 & 26.5 & 0.9 \\
\hline $681 \mathrm{C}-1 \mathrm{H}-3,145-150$ & 4.81 & 5 & 0 & 22 & 7.5 & 10.4 & 7.5 & 22.6 & 8.5 & 16.6 & 0.6 \\
\hline $681 \mathrm{C}-1 \mathrm{H}-3,145-150$ & 6.42 & 9 & 0 & 19.1 & 3.6 & 11.2 & 7.9 & 18.7 & 11.1 & 19.3 & 1.2 \\
\hline $681 C-5 H-3,145-150$ & 2.85 & 10.1 & 0 & 24.5 & 5.9 & 8.6 & 5.8 & 15.6 & 11 & 18.5 & 0.7 \\
\hline $681 \mathrm{~B}-7 \mathrm{H}-2,140-150$ & 1.17 & 7.5 & 0 & 16.6 & 4.6 & 7.6 & 14.1 & 18.8 & 8.6 & 22.3 & 0.9 \\
\hline $681 \mathrm{C}-7 \mathrm{H}-2,140-150$ & 1.76 & 7.2 & 0 & 13.9 & 9.7 & 5.9 & 5.9 & 17.1 & 8.2 & 32.1 & 1.1 \\
\hline 681 B-8I- $1,0-1$ & n.d. & n.d. & n.d. & n.d. & n.d. & n.d. & n.d. & n.d. & n.d. & n.d. & n.d. \\
\hline $681 \mathrm{C}-8 \mathrm{H}-2,140-150$ & 1.12 & 8.2 & 0 & 13.9 & 4.4 & 7.9 & 5.1 & 17.8 & 12.4 & 30.3 & 0.6 \\
\hline $681 \mathrm{~B}-9 \mathrm{H}-1,140-150$ & 1.2 & 8.4 & 0 & 15.9 & 0.8 & 5.7 & 5.7 & 19 & 16.1 & 23.8 & 0.6 \\
\hline $681-\mathrm{C}-9 \mathrm{H}-2,140-150$ & 0.92 & 12.7 & 0 & 19.5 & 9.6 & 7.4 & 3.6 & 15.2 & 7.1 & 24.9 & 0.9 \\
\hline $681 \mathrm{~A}-12 \mathrm{I}-1,0-1$ & n.d. & n.d. & n.d. & n.d. & n.d. & n.d. & n.d. & n.d. & n.d. & n.d. & n.d. \\
\hline $681 \mathrm{~B}-12 \mathrm{X}-3,140-150$ & 2.52 & 7.6 & 0 & 19.6 & 5.2 & 12.5 & 4.7 & 17.6 & 10.6 & 22.3 & 0.8 \\
\hline $681 \mathrm{~B}-15 \mathrm{I}-1,0-1$ & n.d. & n.d. & n.d. & n.d. & n.d. & n.d. & n.d. & n.d. & n.d. & n.d. & n.d. \\
\hline $681 B-15 X-1,135-145$ & 0.77 & 20 & 0 & 13.4 & 4 & 6.4 & 5.1 & 16.7 & 16.6 & 17.8 & 0.5 \\
\hline
\end{tabular}

content (Montani et al., 1982). Both serine and threonine and glycine were assumed to be enriched in the protein template of the silicalemma of diatom cell walls (Hecky et al., 1973; Degens, 1976).

Below 10 mbsf, the THAA composition changes, as indicated by the decrease of aspartic acid and the concomitant increase of the nonproteinaceous amino acids $\beta$-alanine, $\gamma$ amino butyric acid, and ornithine. $\beta$-alanine and $\gamma$-amino butyric acid are thought to be produced by biological decarboxylation of other amino acids like aspartic acid and glycine (Aizenshtat et al., 1973; Vallentyne, 1964). According to Itihara (1973) and Schroeder (1975), $\gamma$-amino butyric acid can also result from chemical diagenesis of glutamic acid. Ornithine may originate either from abiotic and microbial degradation of arginine (Degens, 1970) or from bacterial cell walls (Goossens et al., 1986; Kandler, 1979,1981). Increasing contributions of these amino acids relative to other amino acids with sediment depth were observed in several studies (Aizenshtat et al., 1973; Hare, 1973).

Figure 5 depicts the downhole pattern of the aspartic $\mathrm{acid} / \beta$-alanine and the glutamic acid $/ \gamma$-amino butyric acid ratios in the THAA. A sharp decrease occurs at a depth of about 10 mbsf. Below this depth, both ratios are fairly constant, except at Sample 112-681C-4H-5, 145-150 cm (32.4 mbsf), where a maximum was found; this maximum is discussed later. The close relationship between the two curves may indicate that both ratios are modelled by similar or identical processes. Comparison with the downhole trend of these ratios in other deep-sea drill sites reveals a main difference between carbonate-rich sediments and sediments having low carbonate and high biogenic-opal contents in that both ratios show an increase with depth in carbonate-dominated sediment (Seifert et al., in press). This may be explained by protection of acidic amino acids against early diagenetic degradation owing to their close association with the biogenic carbonate material. Acidic amino acids are known to be major constituents of the organic matrix in calcified skeletons (Weiner et al., 1983; Degens, 1976; King and Hare, 1972) and to be absorbed easily on carbonate particles (Carter and Mitterer, 1978). Schroeder (1975) found amino acid spectra dominated by acidic amino acids in cleaned foraminiferal shell material as old as $40,000 \mathrm{yr}$, while $\beta$-alanine and $\gamma$-amino butyric acid 
Table 4. Amino acids, amino sugars, and GIcN/GalN ratios in hydrolyzed pore water samples from Site 681 .

\begin{tabular}{|c|c|c|c|c|c|c|c|c|c|c|c|c|}
\hline $\begin{array}{l}\text { Core, section, } \\
\text { interval }(\mathrm{cm})\end{array}$ & $\begin{array}{l}\text { Depth } \\
\text { (mbsf) }\end{array}$ & $\begin{array}{c}\text { DHAA } \\
(\mu \mathrm{M})\end{array}$ & $\underset{(\mathrm{mol} \%)}{\text { Asp }}$ & $\begin{array}{c}\text { Thr } \\
(\mathrm{mol} \%)\end{array}$ & $\begin{array}{c}\text { Ser } \\
(\mathrm{mol} \%)\end{array}$ & $\underset{(\mathrm{mol} \%)}{\text { Glu }}$ & $\begin{array}{c}\text { Gly } \\
\text { (mol\%) }\end{array}$ & $\underset{(\mathrm{mol} \%)}{\mathrm{Ala}}$ & $\begin{array}{c}\text { Val } \\
(\mathrm{mol} \%)\end{array}$ & $\begin{array}{c}\text { Met } \\
(\mathrm{mol} \%)\end{array}$ & $\begin{array}{c}\text { Ile } \\
(\mathrm{mol} \%)\end{array}$ & $\underset{(\mathrm{mol} \%)}{\text { Leu }}$ \\
\hline $112-681 \mathrm{C}-1 \mathrm{H}-1,145-150$ & 1.5 & 33.03 & 10.2 & 4.8 & 11.5 & 8.0 & 26.1 & 12.4 & 3.5 & 4.0 & 1.9 & 2.7 \\
\hline $681 \mathrm{~B}-1 \mathrm{H}-2,67-70$ & 2.2 & n.d. & n.d. & n.d. & n.d. & n.d. & n.d. & n.d. & n.d. & n.d. & n.d. & n.d. \\
\hline $681 \mathrm{~B}-1 \mathrm{H}-2,67-70$ & 3.0 & n.d. & n.d. & n.d. & n.d. & n.d. & n.d. & n.d. & n.d. & n.d. & n.d. & n.d. \\
\hline $681 \mathrm{C}-1 \mathrm{H}-3,145-150$ & 4.5 & 13.42 & 8.4 & 3.8 & 15.5 & 9.3 & 23.3 & 11.3 & 2.3 & 0.6 & 1.8 & 2.8 \\
\hline $681 \mathrm{C}-1 \mathrm{H}-3,145-150$ & 7.4 & 17.51 & 9.9 & 5.9 & 14.4 & 6.8 & 30.6 & 9.9 & 2.6 & 0.5 & 1.9 & 2.8 \\
\hline $681 \mathrm{C}-1 \mathrm{H}-3,145-150$ & 11.9 & 18.54 & 8.6 & 3.8 & 18.4 & 15.5 & 23.1 & 4.2 & 2.5 & n.d. & 1.5 & 3.2 \\
\hline $681 \mathrm{C}-1 \mathrm{H}-3,145-150$ & 19.8 & n.d. & n.d. & n.d. & n.d. & n.d. & n.d. & n.d. & n.d. & n.d. & n.d. & n.d. \\
\hline $681 \mathrm{C}-1 \mathrm{H}-3,145-150$ & 27.7 & 3.70 & 5.9 & 3.1 & 17.3 & 13.8 & 16.5 & 5.4 & 4.8 & n.d. & 2.2 & $2 . .7$ \\
\hline $681 \mathrm{C}-1 \mathrm{H}-3,145-150$ & 32.4 & 36.91 & 5.1 & 0.4 & 20.3 & 10.2 & 18.8 & 19.2 & 3.6 & 0.1 & 1.9 & 3.4 \\
\hline $681 \mathrm{C}-5 \mathrm{H}-3,145-150$ & 38.9 & 14.61 & 9.7 & 2.3 & 13.8 & 5.2 & 23.2 & 15.8 & 3.2 & 0.4 & 2.5 & 4.6 \\
\hline $681 \mathrm{~B}-7 \mathrm{H}-2,140-150$ & 56.3 & 27.25 & 8.3 & 4.2 & 16.9 & 17.3 & 22.1 & 5.2 & 2.6 & 0.1 & 1.9 & 2.3 \\
\hline $681 \mathrm{C}-7 \mathrm{H}-2,140-150$ & 56.4 & 17.47 & 8.0 & 3.0 & 14.5 & 11.4 & 18.1 & 14.1 & 5.1 & n.d. & 3.0 & 4.0 \\
\hline $681 \mathrm{~B}-8 \mathrm{I}-1,0-1$ & 64.4 & 20.33 & 5.4 & 0.1 & 20.3 & 6.9 & 37.3 & 8.2 & 1.7 & n.d. & 2.0 & 3.0 \\
\hline $681 \mathrm{C}-8 \mathrm{H}-2,140-150$ & 65.8 & 44.84 & 6.2 & 2.3 & 16.5 & 13.1 & 14.5 & 10.4 & 2.9 & 0.2 & 2.4 & 7.3 \\
\hline $681 \mathrm{~B}-9 \mathrm{H}-1,140-150$ & 73.8 & n.d. & n.d. & n.d. & n.d. & n.d. & n.d. & n.d. & n.d. & n.d. & n.d. & n.d. \\
\hline $681 \mathrm{C}-9 \mathrm{H}-2,140-150$ & 75.3 & n.d. & n.d. & n.d. & n.d. & n.d. & n.d. & n.d. & n.d. & n.d. & n.d. & n.d. \\
\hline $681 \mathrm{~A}-12 \mathrm{I}-1,0-1$ & 94.4 & 20.93 & 3.2 & 4.4 & 27.0 & 17.4 & 26.2 & 1.9 & 2.7 & n.d. & 1.5 & 2.0 \\
\hline $681 B-12 X-3,140-150$ & 98.9 & 149.97 & 10.0 & 6.2 & 19.3 & 11.4 & 19.1 & 6.2 & 3.5 & n.d. & 2.7 & 3.7 \\
\hline 681B-15I-1, 0-1 & 124.6 & 12.22 & 7.9 & 3.0 & 21.9 & 11.0 & 26.9 & 4.5 & 1.1 & n.d. & 2.4 & 3.2 \\
\hline
\end{tabular}

Table 4 (continued).

\begin{tabular}{|c|c|c|c|c|c|c|c|c|c|c|c|}
\hline 1.6 & 1.4 & 2.3 & 0.1 & 3.3 & 3.7 & n.d. & 1.7 & 3.16 & 1497 & 1660 & 0.90 \\
\hline n.d. & n.d. & n.d. & n.d. & n.d. & n.d. & n.d. & n.d. & n.d. & n.d. & n.d. & n.d. \\
\hline 1.4 & 1.0 & 1.1 & 2.3 & 9.6 & 2.2 & 1.9 & 1.3 & 3.69 & 2192 & 1496 & 1.47 \\
\hline 1.2 & 1.3 & 1.5 & 0.2 & 4.1 & 3.1 & n.d. & 3.4 & 2.19 & 1200 & 992 & 1.21 \\
\hline 2.2 & 1.2 & 1.1 & 1.5 & 14.8 & 2.8 & 3.1 & 1.5 & 1.27 & 804 & 470 & 1.71 \\
\hline 1.1 & 0.9 & 0.8 & 0.2 & 2.8 & 6.0 & n.d. & 5.3 & 0.72 & 476 & 243 & 1.96 \\
\hline 0.7 & 0.7 & 1.4 & 1.9 & 6.0 & 4.1 & n.d. & 5.0 & 1.34 & 627 & 609 & 1.03 \\
\hline 1.9 & 1.5 & 0.3 & 0.2 & 8.6 & 2.4 & 2.9 & 1.3 & 0.12 & 96 & 26 & 3.69 \\
\hline 0.9 & 1.0 & 0.6 & 0.6 & 7.9 & 4.5 & n.d. & 3.2 & 0.18 & 127 & 55 & 2.31 \\
\hline 2.1 & 2.5 & 0.6 & 1.0 & 3.5 & 1.6 & n.d. & 4.3 & 0.36 & 213 & 145 & 1.47 \\
\hline 1.7 & 1.5 & 0.7 & 0.5 & 6.2 & 2.2 & 1.7 & 3.2 & 2.82 & 1868 & 951 & 1.96 \\
\hline 1.4 & 1.6 & 0.5 & 0.3 & 6.9 & 3.4 & n.d. & 4.0 & 0.08 & 66 & 16 & 4.13 \\
\hline
\end{tabular}

Table 5. Carbohydrates and distributions of monomers in hydrolyzed pore water samples from Site 681.

\begin{tabular}{|c|c|c|c|c|c|c|c|c|c|c|c|c|}
\hline $\begin{array}{l}\text { Core, section, } \\
\text { interval }(\mathrm{cm})\end{array}$ & $\begin{array}{l}\text { Depth } \\
\text { (mbsf) }\end{array}$ & $\begin{array}{c}\text { DHCHO } \\
(\mu \mathrm{M})\end{array}$ & $\begin{array}{c}\text { Rha } \\
(\mathrm{mol} \%)\end{array}$ & $\begin{array}{c}\text { Rib } \\
(\mathrm{mol} \%)\end{array}$ & $\underset{(\mathrm{mol} \%)}{\operatorname{Man}}$ & $\begin{array}{c}\text { Fru } \\
(\mathrm{mol} \%)\end{array}$ & $\underset{(\mathrm{mol} \%)}{\text { Ara }}$ & $\underset{(\mathrm{mol} \%)}{\text { Fuc }}$ & $\underset{(\mathrm{mol} \%)}{\mathrm{Gal}}$ & $\underset{(\mathrm{mol} \%)}{\mathrm{Xyl}}$ & $\begin{array}{c}\text { Glc } \\
(\mathrm{mol} \%)\end{array}$ & $\begin{array}{c}\mathrm{DHCHO} / \mathrm{DOC} \\
(\%)\end{array}$ \\
\hline $112-681 \mathrm{C}-1 \mathrm{H}-1,145-150$ & 1.5 & 25.17 & 1.4 & 4.1 & 12.4 & 16.4 & 2.1 & 4.2 & 7.6 & 2.7 & 49.2 & 6.1 \\
\hline $681 \mathrm{~B}-1 \mathrm{H}-2,67-70$ & 2.2 & n.d. & n.d. & n.d. & n.d. & n.d. & n.d. & n.d. & n.d. & n.d. & n.d. & n.d. \\
\hline $681 \mathrm{~B}-1 \mathrm{H}-2,67-70$ & 3.0 & n.d. & n.d. & n.d. & n.d. & n.d. & n.d. & n.d. & n.d. & n.d. & n.d. & n.d. \\
\hline $681 \mathrm{C}-1 \mathrm{H}-3,145-150$ & 4.5 & n.d. & n.d. & n.d. & n.d. & n.d. & n.d. & n.d. & n.d. & n.d. & n.d. & n.d. \\
\hline $681 \mathrm{C}-1 \mathrm{H}-3,145-150$ & 7.4 & 14.36 & 6.7 & 7.6 & 9.5 & 15.7 & 2.9 & 2.2 & 8.7 & 3.9 & 42.8 & 5.4 \\
\hline $681 \mathrm{C}-1 \mathrm{H}-3,145-150$ & 11.9 & 23.03 & 14.1 & n.d. & 7.1 & 29.0 & 1.5 & 2.5 & 7.5 & 3.8 & 34.4 & 6.1 \\
\hline $681 \mathrm{C}-1 \mathrm{H}-3,145-150$ & 19.8 & 20.70 & n.d. & n.d. & 4.6 & 23.1 & 4.5 & 2.4 & 8.9 & 1.9 & 54.7 & 8.0 \\
\hline $681 \mathrm{C}-1 \mathrm{H}-3,145-150$ & 27.7 & 23.09 & 3.2 & 6.4 & 6.8 & 12.4 & 2.0 & 7.8 & 13.5 & 7.0 & 41.0 & 5.8 \\
\hline $681 \mathrm{C}-1 \mathrm{H}-3,145-150$ & 32.4 & 17.18 & 5.2 & 0.9 & 11.7 & 17.8 & 4.0 & 2.2 & 13.2 & 8.2 & 36.7 & 3.8 \\
\hline $681 \mathrm{C}-5 \mathrm{H}-3,145-150$ & 38.9 & n.d. & n.d. & n.d. & n.d. & n.d. & n.d. & n.d. & n.d. & n.d. & n.d. & n.d. \\
\hline $681 \mathrm{~B}-7 \mathrm{H}-2,140-150$ & 56.3 & 8.87 & n.d. & 5.9 & 5.9 & 10.1 & 6.7 & n.d. & 15.8 & 25.7 & 30.7 & 2.7 \\
\hline $681 \mathrm{C}-7 \mathrm{H}-2,140-150$ & 56.4 & 49.25 & 1.5 & 0.4 & 0.1 & 46.2 & 0.1 & 0.1 & 1.6 & 0.5 & 49.6 & 21.9 \\
\hline $681 \mathrm{~B}-8 \mathrm{I}-1,0-1$ & 64.4 & 10.07 & n.d. & n.d. & 1.6 & 19.2 & 2.2 & n.d. & 3.9 & 3.2 & 69.9 & 6.5 \\
\hline $681 \mathrm{C}-8 \mathrm{H}-2,140-150$ & 65.8 & 5.81 & n.d. & n.d. & 2.4 & 30.7 & n.d. & n.d. & 8.1 & 3.8 & 55.0 & 2.7 \\
\hline $681 \mathrm{~B}-9 \mathrm{H}-1,140-150$ & 73.8 & n.d. & n.d. & n.d. & n.d. & n.d. & n.d. & n.d. & n.d. & n.d. & n.d. & n.d. \\
\hline $681 \mathrm{C}-9 \mathrm{H}-2,140-150$ & 75.3 & n.d. & n.d. & n.d. & n.d. & n.d. & n.d. & n.d. & n.d. & n.d. & n.d. & n.d. \\
\hline $681 \mathrm{~A}-12 \mathrm{I}-1,0-1$ & 94.4 & 30.53 & 1.1 & n.d. & 4.4 & 27.8 & n.d. & n.d. & 4.0 & 1.6 & 61.1 & n.d. \\
\hline $681 \mathrm{~B}-12 \mathrm{X}-3,140-150$ & 98.9 & n.d. & n.d. & n.d. & n.d. & n.d. & n.d. & n.d. & n.d. & n.d. & n.d. & n.d. \\
\hline $681 \mathrm{~B}-15 \mathrm{I}-1,0-1$ & 124.6 & n.d. & n.d. & n.d. & n.d. & n.d. & n.d. & n.d. & n.d. & n.d. & n.d. & n.d. \\
\hline $681 \mathrm{~B}-15 \mathrm{X}-1,135-145$ & 126.0 & n.d. & n.d. & n.d. & n.d. & n.d. & n.d. & n.d. & n.d. & n.d. & n.d. & n.d. \\
\hline
\end{tabular}




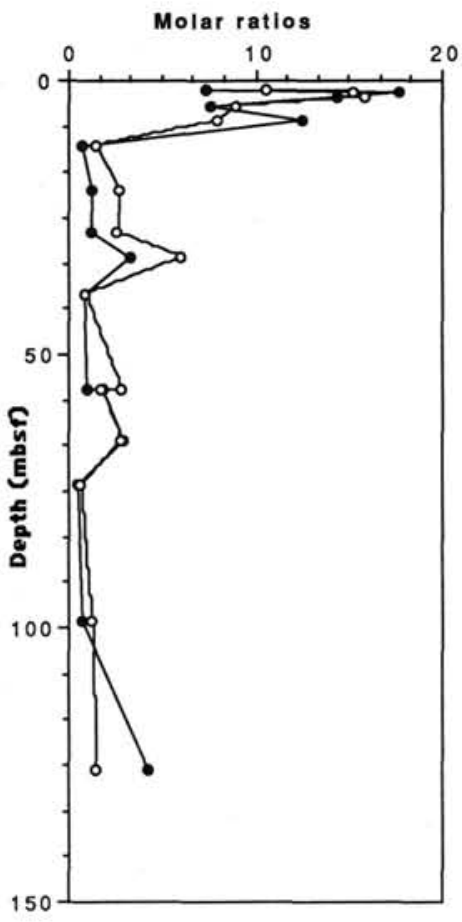

Figure 5. Ratios of aspartic acid/ $\beta$-alanine $(\bullet)$ and glutamic acid/ $\gamma$-amino butyric acid (o) in the particulate amino acid fraction vs. depth.

were missing. Decreasing molar fractions of acidic amino acids have been reported for the upper centimeters or meters of reducing sediments in several previous studies (Maita et al., 1982; Henrichs et al., 1984; Burdige and Martens, 1988).

Our analyses of the DHAA and DHCHO contents of interstitial waters show no decrease with depth, in contrast to THAA and THCHO. This same behavior was observed in cores of other deep-sea sediments (Seifert et al., in press). While bulk dissolved amino compounds show no downhole trend, data for the fraction of dissolved free amino acids (DFAA) in interstitial waters indicate a downhole decrease for this part of the DHAA (Henrichs and Farrington, 1984; 1987). According to these results one can assume that DFAA contribute only a small portion to the DHAA in deeper sediments, such as those investigated here. In comparison with the THAA, the DHAA are generally enriched in glycine, serine, glutamic acid, and aspartic acid, while valine, iso-leucine, leucine, and phenylalanine are depleted (Fig. 3). Interestingly, those amino acids that reveal a downhole decrease in their contribution to the THAA, i.e., serine, glycine, and glutamic acid, are enriched in the DHAA. In contrast, those amino acids that are depleted in the DHAA, i.e., valine, iso-leucine, leucine, and phenylalanine, show increasing percentages in the THAA with depth and must be more stable (Fig. 6). This is likely to be an expression of the dependence of DHAA production from degradation of THAA by microbes, whereby proteinaceous organic matter is broken up into individual amino acids.

Total concentration of THAS (Table 1) reveals a downhole trend somewhat different from THAA and THCHO. Although THAS values were found to be, on the average, higher in the upper part of the core, their decrease is less pronounced with depth than that of either THAA or THCHO. This relative enrichment of amino sugars in the sediments is accompanied by an opposite trend in the dissolved fraction. The DHAA/ DHAS ratio increases strongly in the deeper part of the core,
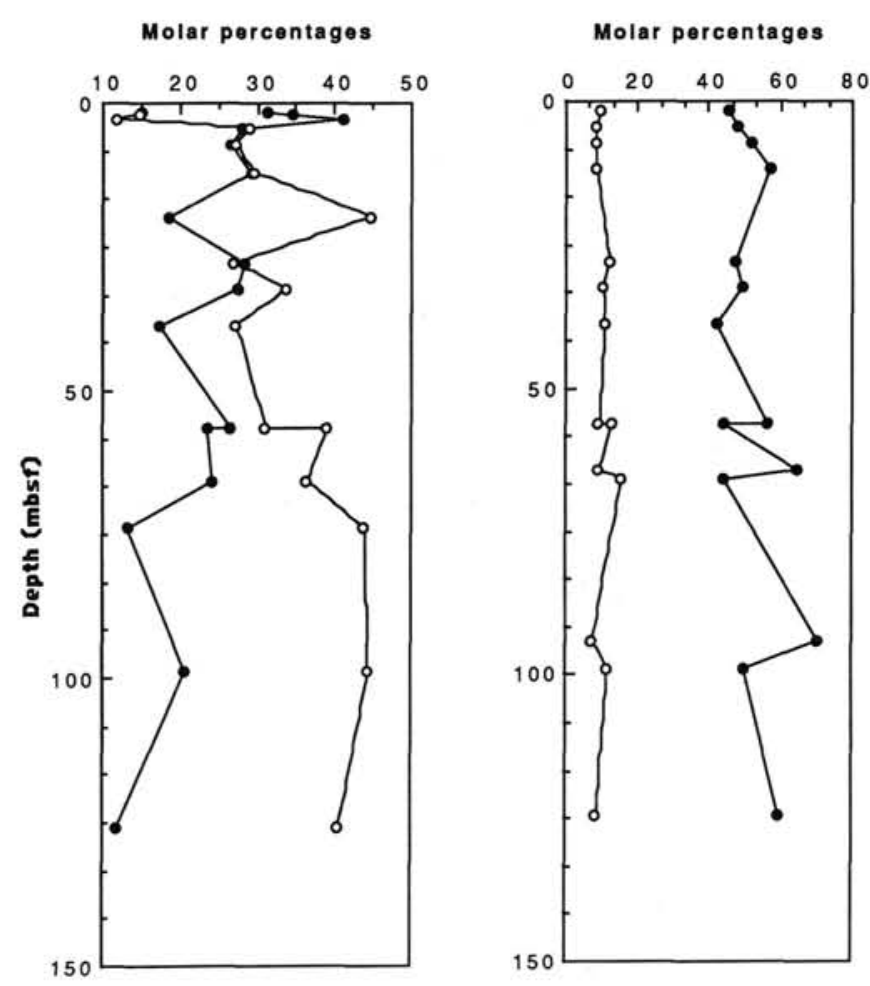

Figure 6. A. Downhole changes in molar contributions for valine + iso-leucine + leucine + phenylalanine (o) and serine + glutamic acid + glycine (•) of amino acids in sediments. Note the inverse relationship, which is indicative of ongoing diagenetic fractionation of amino acids at depth! B. The same groups in pore waters.

and the contribution of DHAS to DOC is low. Thus, the amino sugars exhibit a pattern similar to amino acids like valine, iso-leucine, leucine, and phenylalanine. The inverse relationship between the concentration of these compounds in the particulate and dissolved phases suggests slower rates of (bacterially mediated) hydrolysis. Feasible mechanisms for the observed disparity in hydrolysis rates are either selective transfer from the particulate to the dissolved phase by desorption from or by decomposition of large molecules or aggregates, or a selective fractionation of amino compounds in the dissolved pool through adsorption and condensation processes onto particles.

Most of the sediment samples in the upper part of the analyzed core exhibit THAA/THAS ratios of between 3 and 14 , a range that is to be expected for mixtures of diatomaceous and bacterial cell walls. Hecky et al. (1973) found amino acid/amino sugar ratios between 11 and 190 in the cell walls of six different diatom species. Analyses of bacterial cell walls revealed amino acid/amino sugar ratios of about 4 (Kandler and König, 1978).

Downhole, the GlcN/GalN ratio increases in the sediments and in the interstitial water, with highest values in Unit II. A similar increase of this ratio with depth was found in sediments from the Black Sea (Mopper et al., 1978) and the Tyrrhenian Sea (Seifert et al., in press). Analyses of suspended matter, sediment-trap material, and surface sediment in marine environments revealed highest GlcN/GalN ratios in the particulate matter of the upper water column and very low ratios in surface sediments (Steinberg et al., 1987; Bartsch, 1987). These observations and the downhole increase of the GlcN/GalN ratio in the sediments investigated here underscore the enrichment of GalN relative to $\mathrm{GlcN}$ in the upper 


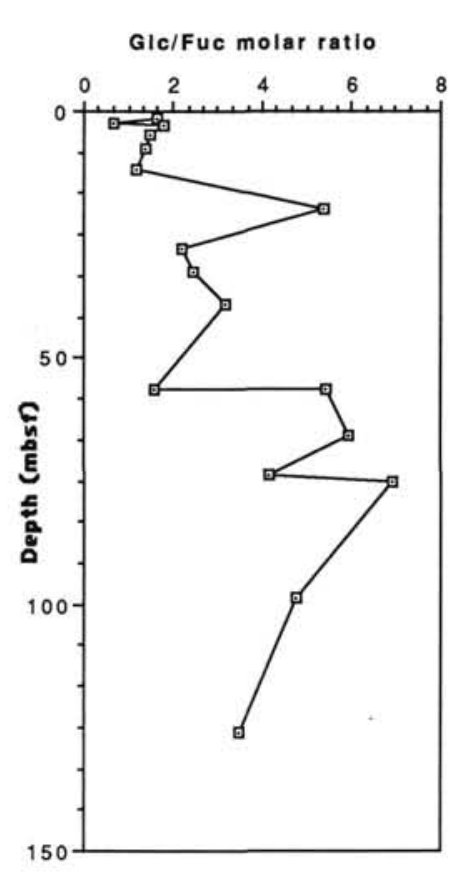

Figure 7. Glucose/fucose ratios in sediments vs. depth

sediment layers. GlcN/GalN ratios below 1 are typical for cell walls of various bacterial species (Reistad, 1975; Kandler and König, 1978; Kandler, 1979). Therefore, low ratios might coincide with high bacterial biomass.

High ratios of GlcN/GalN are presumed to result from an enrichment of chitin, either from high zooplankton contributions, or as a residue of hexoseamines because of the higher stability of chitinaceous material during early diagenetic decomposition. GlcN/GalN changes in the water column and the surface sediment from extensive dissolution of chitin (Steinberg et al., 1987) should be accompanied by a strong decrease in the total amount of particulate hexoseamines in the water column. Such a decrease in the total hexoseamine content is not indicated by investigation of sediment trap material (Ittekkot et al., 1984a; 1984b). In addition, such a process does not explain the increase of this ratio with depth in the sediment investigated here. We tend to believe that the main processes modeling the GlcN/GalN ratio are bacterial activity and preferential hydrolysis of GalN from an unknown source in the sediments. We found no indications for a significant influence of more refractory matter, as would be expected from recycled or terrestrial material.

\section{Carbohydrates}

The concentration of THCHO is highest in the upper meters of the sediment column and decreases exponentially with depth. While THCHO contribution to TOC is smaller in the upper $10 \mathrm{~m}$ than that of THAA, the ratio of THCHO/ THAA is near 1 in most samples below 10 mbsf (Table 1). The carbohydrate fraction of the sediment is apparently more stable during early diagenesis, and the amount preserved is less dependent on the quality of organic matter. Vascular plant tissue contains significantly more carbohydrates than either planktonic or bacterial biomass (Cowie and Hedges, 1984). While variability in the carbohydrate/amino acid ratio could indicate terrestrial influx (Mopper et al., 1978), sediment from the Peru margin is notoriously low in terrestrial plant remains (D. Hoiser, pers. comm., 1988). Thus, we prefer to

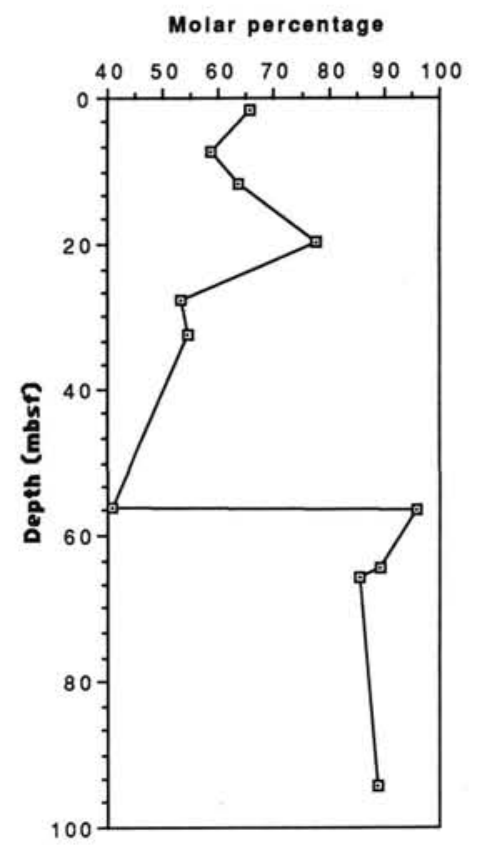

Figure 8. Molar percentages of fructose + glucose in pore waters vs. depth.

attribute the decrease in the THAA/THCHO ratios with depth to different decomposition rates.

Additional insight into the composition of organic matter is given by comparing individual carbohydrate spectra. Michaelis et al. (1986) used the relative abundance of glucose and fructose as indications for terrigenous influx as cellulose, while high galactose, mannose, and xylose contents were used to characterize marine material (Mycke et al., 1985; Ittekkot et al., 1984a, 1984b). Figure 7 depicts the downhole distribution of the glucose/fucose ratio with depth. Fucose was chosen because of high fucose concentrations in diatom frustules (12.2 to $42.5 \mathrm{~mol} \%$; Hecky et al., 1973) and the low fucose content in vascular plant material (Cowie and Hedges, 1984). At Site 681, low ratios indicative of marine influx occur in the upper part of the profile, while we observed a terrestrial signature of high ratios in Sample 112-681B-3H-3, 140-150 cm of lithologic Unit I and throughout most of lithologic Unit II. Based on sedimentary evidence, Unit II was deposited under more terrestrial influence, while Unit I is dominated by deposition of marine material under influence of upwellingrelated high productivity and the oxygen-minimum zone.

The concentration of $\mathrm{DHCHO}$ in the interstitial waters does not appear to be influenced by the amount and composition of sugars in the solid phase. The DHCHO spectra appear to be enriched in glucose and fructose and depleted in rhamnose, mannose, galactose, arabinose, fucose, and xylose (Fig. 4). Such an enrichment of glucose and fructose in pore water, seawater, and groundwater has been described by various authors (Mopper et al., 1980; Ittekkot et al., 1981; Spitzy, 1982; Emeis et al., 1987; Seifert et al., in press). We attribute this dominance of glucose and fructose to a higher stability and a selective enrichment of these two sugars in solution, which may result from either chelation by metal ions (in the case of fructose) or lower utilization of dissolved glucose by bacteria. Mopper et al.(1980) presented a comprehensive discussion of this problem. Figure 8 depicts the downhole contribution of glucose and fructose to DHCHO in the pore waters of Site 681 . High contributions are apparent at $19.8 \mathrm{mbsf}$ and in the lower part of the profile; these resemble 
the shape of the of glucose/fucose ratios in the particulate carbohydrate fraction with depth (Fig. 7).

In the downhole plots of concentrations and ratios discussed above, some samples appear to be irregular or exhibit trends inconsistent with the rest of the samples. Sample 112-681B$1 \mathrm{H}-2,145-150 \mathrm{~cm}$ ( $3 \mathrm{mbsf})$ has a very low TOC content when compared to samples below or above, even though neither THAA, THAS, and THCHO contributions to TOC nor the spectra of individual amino compounds of sugars differ from the neighboring samples. We attribute this to dilution with clastics, because the organic matter composition and state of preservation is similar to the surrounding sediment.

Sample 112-681B-3H-3, 140-150 cm (19.8 mbsf) differs significantly in the quality of the organic matter when compared to other samples from lithologic THCHO spectra similar to those from samples of deeper, presumably more terrigenous, zones of Unit II, indicating a high portion of refractory nonproteinaceous material in the organic matter. These observations and the appearance of grading in the first $3 \mathrm{~cm}$ of interval $112-681 \mathrm{~B}-3 \mathrm{H}-4,1-3 \mathrm{~cm}$, led us to assume that this zone includes allochthonous organic material that has undergone resuspension and more severe degradation before it was deposited.

By contrast, Sample 112-681C-4H-5, 145-150 cm $(32.4$ mbsf) resembles samples from the first $10 \mathrm{~m}$ of the profile. High aspartic acid/ $\beta$-alanine and glutamic acid $/ \gamma$-amino butyric acid ratios and a high contribution of acidic amino acids (Fig. 6), together with low portions of glucose and fructose in the $\mathrm{THCHO}$, are indicators of organic material that has degraded very little.

Samples 112-681B-7H-2, 140-150 cm (56.3 mbsf) and 112$681 \mathrm{C}-7 \mathrm{H}-2,140-150 \mathrm{~cm}(56.4 \mathrm{mbsf})$ are similar in their TOC content but reveal significant differences in concentrations and distributions of amino compounds and sugars. Contents of THAA and THAS are about 5 and 18 times higher in Sample $112-681 \mathrm{~B}-7 \mathrm{H}-2,140-150 \mathrm{~cm}$, than in the second sample at approximately the same depth (Table 1). In addition, the two samples are distinguished by the glucose/fucose ratio in the THCHO (Fig. 7), as well as by the contribution of glucose + fructose in the DHCHO (Fig. 8). Sample 112-681B-7H-2, $140-150 \mathrm{~cm}$, matches Sample 112-681B-1H-2, 145-150 cm, at a much shallower depth and is distinct from all other samples in Unit II. The significant difference between the two samples indicates that Holes $681 \mathrm{~B}$ and $681 \mathrm{C}$ probably did not penetrate exactly the same sequence of sediments and may be offset considerably.

\section{CONCLUSIONS}

The distribution of amino compounds and carbohydrates seems to be linked to variations in source materials, microbial activity, and time since burial, rather than to abundance of organic matter. Variations in the contributions of terrigenous (allochthonous) and marine (autochthonous) organic matter are not obvious from the total amount of organic carbon, but find their expression in the contribution and composition of amino acids, amino sugars, and carbohydrates. We could not discern a simple relationship between the total amounts of particulate amino compounds and sugars to the corresponding dissolved phase in interstitial waters, but in some cases, particulate and dissolved monomers show similar or inverse distributions. Owing to the presumed short residence time of dissolved amino compounds and carbohydrates in DOC and owing to different remineralization rates of particulate and dissolved compounds, some carbohydrate monomers and amino acids have been enriched in both particulate and dissolved phases. Amino acids, such as valine, iso-leucine, leucine, phenylalanine, and hexose- amines that show a general increase in THAA with depth, are depleted in the dissolved phase. Other amino acids enriched in the dissolved phase are depleted in the corresponding sediment. With regard to indications of bacterial activity, the glucoseamine/galactoseamine ratio appears to be a useful indicator of decomposition processes and bacterial biomass.

\section{ACKNOWLEDGMENTS}

Financial support by the Deutsche Forschungsgemeinschaft and technical support by the Ocean Drilling Program are gratefully acknowledged. We appreciate the reviews and improvements suggested by A. Sigleo, R. Mitterer, W. Dean, and the ODP volume editor. We further thank M. Sternhagen for laboratory assistance.

\section{REFERENCES}

Aizenshtat, Z., Baedecker, M. J., and Kaplan, I. R., 1973. Distribution and diagenesis of organic compounds in JOIDES sediment from Gulf of Mexico and western Atlantic. Geochim. Cosmochim. Acta, 37:1881-1898.

Bartsch, M., 1987. Laterale und vertikale Verteilung von Zuckern und Aminosäuren im Arabischen Meer-Indikatoren für Abbauprozesse und Sedimentationsgeschehen [Diplomarbeit Universität Hamburg]. Fachbereich Geowissenschaften, 126.

Burdige, D. J., and Martens, C. S., 1988. Biogeochemical cycling in an organic-rich coastal marine basin: 10 . The role of amino acids in sedimentary carbon and nitrogen cycling. Geochim. Cosmochim. Acta, 52:1571-1584.

Carter, P. W., and Mitterer, R. M., 1978. Amino acid composition of organic matter associated with carbonate and non-carbonate sediments. Geochim. Cosmochim. Acta, 42:1231-1238.

Cowie, G. L., and Hedges, J. I., 1984. Carbohydrate sources in coastal marine environment. Geochim. Cosmochim. Acta, 48:2075-2087.

Degens, E. T., 1970. Molecular nature of nitrogenous compounds in seawater and recent sediments. In Hood, D. W. (Ed.), Organic Matter in Natural Water. Inst. Mar. Sci. Alaska, 1:77-106.

1976. Molecular mechanisms on carbonate, phosphate and silica deposition in the living cell. Topics in Current Chemistry, 64:1-112.

Degens, E. T., Reuter, J. R., and Shaw, K.N.F., 1964. Biochemical compounds in offshore California sediments and sea waters. Geochim. Cosmochim. Acta, 28:45-66.

Emeis, K.-C., Mycke, B., Richnow, H.-H., Spitzy, A., and Degens, E. T., 1987. Organic carbon and nitrogen, sediment composition, and clay mineralogy of DSDP Site 603, Western Atlantic Ocean. In Van Hinte, J. E., Wise, S. W., Jr., et al., Init. Repts. DSDP, 93: Washington (U.S. Govt. Printing Office), 1245-1256.

Gieskes, J. M., and Peretsman, G., 1986. Water-chemistry procedures aboard JOIDES Resolution-some comments. ODP Technical Note, 5:1-46

Goossens, H., Irene, W., Rijpstra, C., Duren, R. R., De Leeuw, J. W., and Schenck, P. A., 1986. Bacterial contribution to sedimentary organic matter; a comparative study of lipid moieties in bacteria and recent sediments. In Leythäuser, D., and Rullkötter, J. (Eds.), Advances in Organic Geochemistry 1985: Oxford (Pergamon Press), 683-696.

Hamilton, S. E., and Hedges, J. I., 1988. The comparative geochemistries of lignins and carbohydrates in an anoxic fjord. Geochim. Cosmochim. Acta, 52:129-142.

Hare, P. E., 1973. Amino acids, amino sugars, and ammonia in sediments from the Cariaco Trench. In Heezen, B. C., and MacGregor, I. D., et al., Init. Repts. DSDP, 20: Washington (U.S. Govt. Printing Office), 941-942.

Hecky, R. E., Mopper, K., and Degens, E. T., 1973. The amino acid and sugar composition of diatom cell-walls. Mar. Biol., 19:323331.

Henrichs, S. M., and Doyle, A. P., 1986. Decomposition of ${ }^{14} \mathrm{C}$ labelled organic substances in marine sediments. Limnol. Oceanogr., 31:765-778.

Henrichs, S. M., and Farrington, J. W., 1984. Peru upwelling region sediments near $15^{\circ} \mathrm{S}$. 1. Remineralization and accumulation of organic matter. Limnol. Oceanogr., 29:1-19. 
1987. Early diagenesis of amino acids and organic matter in two coastal marine sediments. Geochim. Cosmochim. Acta, 51:1-15. Henrichs, S. M., Farrington, J. W., and Lee, C. W., 1984: Peru upwelling region sediments near $15^{\circ} \mathrm{S} .2$. Dissolved free and total hydrolyzable amino acids. Limnol. Oceanogr., 29:20-34.

Itihara, Y., 1973. Amino acids in the Cenozoic sediments of Japan. Pacific Geol., 6:51-63.

Ittekkot, V., Brockmann, U., Michaelis, W., and Degens, E. T., 1981. Dissolved free and combined carbohydrates during a phytoplankton bloom in the Northern North Sea. Mar. Ecol., 4:299305.

Ittekkot, V., Degens, E. T., and Honjo, S., 1984a. Seasonality in the fluxes of sugars, amino acids, and amino sugars to the deep ocean: Panama Basin. Deep-Sea Res., 31:1071-1083.

1984b. Seasonality in the fluxes of sugars, amino acids, and amino sugars to the deep ocean. Sargasso Sea. Deep-Sea Res., 31:1057-1069.

Kandler, O., 1979. Zellwandstrukturen bei Methan-Bakterien. Naturwissenschaften, 66:95-105.

1981. Archaebakterien und Phylogenie der Organismen. Naturwissenschaften, 68:183-192.

Kandler, O., and König, H., 1978. Chemical composition of the Peptidoglycan-free cell walls of methanogenic bacteria. Arch. Microbiol., 118:114-152.

King, K., Jr., and Hare, P. E., 1972. Amino acid composition of planctonic foraminifera: a paleobiochemical approach to evolution. Science, 175:1461-1463.

Maita, Y., Montani, S., and Ishii, J., 1982. Early diagenesis of amino acids in Okhotsk Sea sediments. Deep-Sea Res., 29(4A):485-498.

Michaelis, W., and Ittekkot, V., 1982. Biogeochemistry of rivers: field and analytical techniques. In Degens, E. T. (Ed.), Transport of Carbon and Minerals in Major World Rivers, Pt. 1. Mitt. Geol. Pal. Inst. Univ. Hamburg, 52:69-89.

Michaelis, W., Mycke, B., and Richnow, H.-H., 1986. Organic chemical indicators for reconstructions of Angola Basin sedimentation processes. In Degens, E. T., Meyers, A., and Brassell, S. C. (Eds.), Biochemistry of Black Shales. Mitt. Geol.-Palaont. Inst. Univ. Hamburg, 60:99-113.

Montani, S., Maita, Y., and Fukase, S., 1982. Possible occurrence of diatom cell wall-derived amino acids in Okhotsk Sea sediments. Geochemical J., 16:585-603.

Mopper, K., 1977. Sugars and uronic acids in sediments and water from Black Sea and North Sea with emphasis on analytical techniques. Mar. Chem., 5:585-603.

1978. Improved chromatographic separation on an anion exchange resin, III. Sugars in borate medium. Analyt. Biochem., 87:162-168.

Mopper, K., Michaelis, W., Garrasi, C., and Degens, E. T., 1978. Sugars, amino acids and hydrocarbons in Black Sea sediment from
DSDP Leg 42 cores. In Ross, D. A., Neprochnov, Y. P., et al., Init. Repts. DSDP, 42(Pt. 2): Washington (U.S. Govt. Printing Office), 697-705.

Mopper, K., Dawson, R., Liebezeit, G., and Ittekkot, V., 1980. The monosaccharide spectra of natural waters. Mar. Chem., 10:55-66.

Mycke, B., Emeis, K.-C., and Degens, E. T., 1985. Diagenesis of organic compounds in Hole 593, Leg 90. In Kennett, J. P., von der Borch, C. C., et al., Init. Repts. DSDP, 90: Washington (U.S. Govt. Printing Office), 1265-1269.

Reistad, R., 1975. Amino sugars and amino acids constituents of the cell walls of the extremely halophilic cocci. Arch. Microbiol., 102:71-73.

Romankevich, E. A., 1984. Geochemistry of Organic Matter in the Ocean: Berlin, Heidelberg, New York, Tokyo (Springer-Verlag).

Schroeder, R. A., 1975. Absence of $\beta$-alanine and $\gamma$-aminobutyric acid in cleaned foraminiferal shells: implications for use as a chemical criterion to indicate removal of non-indigenous amino acid contaminants. Earth Planet Sci. Lett., 25:274-278.

Seifert, R., Emeis, K.-C., Spitzy, A., Strahlendorf, K., Michaelis, W., and Degens, E. T., in press. Geochemistry of labile organic matter in sediments and interstitial waters recovered from Sites 651 and 653, Leg 107 in the Tyrrhenian Sea. In Kastens, K. A., Mascle, J., et al., Proc. ODP, Sci. Results, 107.

Spitzy, A., 1982. Amino acids and sugars in deep and shallow groundwater in Hamburg. In Degens, E. T. (Ed.), Transport of Carbon and Minerals in Major World Rivers, Pt. 1. Mitt. Geol.Paläont. Inst. Univ. Hamburg, 52:743-748.

Steinberg, S. M., Venkatesan, M. I., and Kaplan, I. R., 1987. Organic geochemistry of sediments from the continental margin off southern New England, U.S.A.-part 1. Amino acids, carbohydrates, and lignin. Mar. Chem., 21:249-265.

Suess, E., von Huene, R., et al., 1988. Proc. ODP, Init. Repts., 112: College Station, TX (Ocean Drilling Program).

Suess, E., Kulm, L. D., and Killingley, J. S., 1987. Coastal upwelling and a history of organic-rich mudstone deposition off Peru. In Brooks, J., and Fleet, A. J. (Eds.), Marine Source Rocks. Geol. Soc. Am. Spec. Publ., 26:181-197.

Vallentyne, J. R., 1964. Biogeochemistry of organic matterII-thermal reaction kinetics and transformation products of amino compounds. Geochim. Cosmochim. Acta, 28:157-188.

Weiner, S., Taub, W., and Lowenstam, H. A., 1983. Organic matrix in calcified exoskeletons. In Westbroek, P., and De Jong, E. W. (Eds.), Biomineralization and biological Metal Accumulation: Dordrecht-Boston-London (D. Reidel), 205-224.

Date of initial receipt: 8 November 1988

Date of acceptance: 24 August 1989

Ms 112B-152 